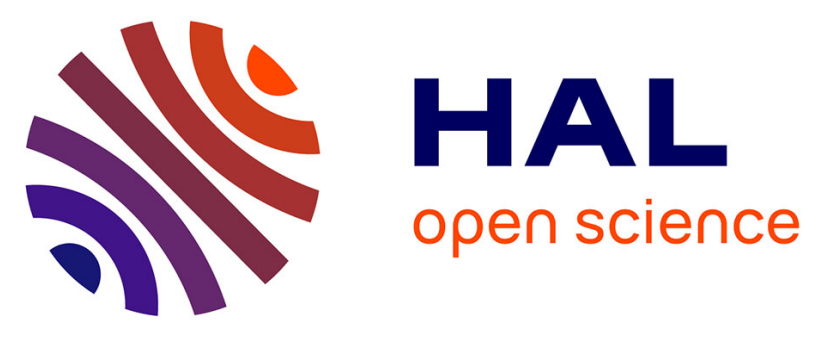

\title{
Late Neanderthal short-term and specialized occupations at the Abri du Maras (South-East France, level 4.1, MIS 3)
}

Marie-Helene Moncel, M. Gema Chacón, Delphine Vettese, Marie-Agnès Courty, Aleix Eixea, Camille Daujeard, Paul Fernandes, Ethel Allué, Bruce Hardy, Rosalia Gallotti, et al.

\section{To cite this version:}

Marie-Helene Moncel, M. Gema Chacón, Delphine Vettese, Marie-Agnès Courty, Aleix Eixea, et al.. Late Neanderthal short-term and specialized occupations at the Abri du Maras (South-East France, level 4.1, MIS 3). Archaeological and Anthropological Sciences, 2021, 13 (3), pp.45. 10.1007/s12520021-01285-5 . hal-03146408

\section{HAL Id: hal-03146408 https://hal.science/hal-03146408}

Submitted on 31 Mar 2021

HAL is a multi-disciplinary open access archive for the deposit and dissemination of scientific research documents, whether they are published or not. The documents may come from teaching and research institutions in France or abroad, or from public or private research centers.
L'archive ouverte pluridisciplinaire HAL, est destinée au dépôt et à la diffusion de documents scientifiques de niveau recherche, publiés ou non, émanant des établissements d'enseignement et de recherche français ou étrangers, des laboratoires publics ou privés. 
Late Neanderthal short-term and specialized occupations at the Abri du Maras (South-East France, level 4.1, MIS 3)

Marie-Hélène Moncel1-(*), M. Gema Chacón1-2-3, Delphine Vettese1-4-5, Marie-Agnès Courty6, Camille Daujeard1, Aleix Eixea7-8, Paul Fernandes9, Ethel Allué-2-3, Bruce Hardy10, Florent Rivals2-3-14, Philippe Béarez11, Rosalia Gallotti12-13, Simon Puaud1

${ }^{1}$ UMR7194 - HNHP (CNRS - MNHN -UPVD - Sorbonne Universités), 1 rue René Panhard, 75013 Paris, France (*Correspondant author : marie-helene.moncel@mnhn.fr)

${ }^{2}$ Institut Català de Paleoecologia Humana i Evolució Social (IPHES), Zona Educacional 4, Campus Sescelades URV (Edifici W3), 43007 Tarragona, Spain

${ }^{3}$ Universitat Rovira i Virgili (URV), Departament d'Història i Història de l'Art, Av. Catalunya 35, 43002 Tarragona, Spain

${ }^{4}$ Università di Ferrara, Dipartimento di Studi Umanistici, Sezione di Scienze Preistoriche e Antropologiche, Corso Ercole I D'Este 32, Ferrara, 44100, Italy

${ }^{5}$ Instituto Internacional de Investigaciones Prehistóricas de Cantabria, (Universidad de Cantabria, Santander, Gobierno de Cantabria), Santander, 39005, Spain

${ }^{6}$ CNRS-UPR 8521 PROMES. Procédés et Matériaux Solaires. Rambla de la Thermodynamique. Tecnosud, Perpignan, FR 66100, France

7 Universitat de València, Departament de Prehistòria, Arqueologia i Història Antiga, Av. Blasco Ibañez 28, 46010 Valencia, Spain

${ }^{8}$ Grupo de Investigación Prehistoria del Mediterráneo Occidental (PREMEDOC), Universitat de València, Spain

${ }^{9}$ Paleotime, Villars-de-Lens, France

${ }^{10}$ Dept. of Anthropology, Kenyon College, Gambier, Ohio, USA

${ }^{11}$ Archéozoologie, archéobotanique : sociétés, pratiques et environnements (UMR 7209, AASPE), MNHN, CNRS, 55 rue Buffon, CP 56, 75005 Paris, France

${ }^{12}$ Université Paul Valéry Montpellier 3, CNRS, UMR 5140 Archéologie des sociétés méditerranéennes, Campus Saint Charles, 34199 Montpellier (France)

13 Université Bordeaux 1 UMR 5199 PACEA-PPP, Bâtiment B18 allée Geoffroy Saint-Hilaire CS 50023 F 33615 Pessac Cedex (France)

${ }^{14}$ ICREA, Pg. Lluís Companys 23, 08010 Barcelona, Spain

This article is part of the Topical Collection on Settlement Patterns Dynamics of the Middle Paleolithic and Middle Stone Age

\section{Abstract}

Level 4.1 from the Abri du Maras (Ardèche, France) is chronologically attributed to the beginning of MIS 3 and is one example of late Neanderthal occupations in the southeast of France. Previous work on the faunal and lithic remains suggest that this level records short-term hunting episodes of reindeer associated with fragmented lithic reduction sequences. During fieldwork, the high density of the material did not allow identification of clear spatial patterning of these activities. In order to try to decipher the palimpsest of these short-term occupations, we combined contextual micro-stratigraphic analysis with interdisciplinary and methodological approaches to obtain high-resolution intra-site spatial data. The former was performed by studying microfacies variability of occupation layers at meso to microscales. A combination of spatial techniques based on GIS and kernel density analysis, along with faunal and lithic refitting was used and focused on the horizontal distribution of the whole archaeological assemblage.

The results demonstrate that quantitative approaches, associated with the interdisciplinary empirical processing of data, are suitable and adequate methods for describing the spatio-temporal formation of the archaeological assemblage. This integrated approach allowed us to identify a temporal succession of occupational events marked by distinctive anthropic imprints in the host matrix in well-preserved activity 
54 areas. The analysis of their spatial patterns reveals differential treatment of lithic and faunal remains. We 55 describe the possible organization of the settlement patterns dynamics of these specialized short-term 56 occupations.

58 Keywords: Middle Palaeolithic, late Neanderthal, Abri du Maras, France, fauna and lithic refits, spatial 59 pattern analysis, short-term occupations 


\section{Introduction}

The interpretation of lithic and faunal assemblages in terms of human settlement patterns is one of the main issues in Prehistoric Archaeology for reconstructing behavioural strategies. Most Middle Palaeolithic assemblages are viewed as palimpsests formed from successive episodes of occupation that cannot be individually identified (Bailey 2007). They originate from the convergence into a single space of anthropogenic events with depositional, erosional and post-depositional processes (Lucas 2005, 2012) which is exclusively defined by stratigraphic criteria (Vaquero 2008). Even in archaeological contexts of high temporal resolution, each stratigraphically-expressed palimpsest is acknowledged to integrate successive occupation events (i.e. Julien et al. 1992; Vaquero 2008, Malinsky-Buller et al. 2011; Henry 2012; Vaquero et al. 2012a; Chacón et al. 2015; Machado et al. 2013, 2019; Mallol et al. 2019; Real et al. 2019).

A variety of methods have been used to attempt to identify behaviourally significant spatial patterns in terms of activities performed by Neanderthals (i.e. Adler and Conard 2005; Henry 2012; Bargalló et al. 2016; 2020; Chacón et al. 2015; Dibble et al. 2018; Ekshtain et al. 2019; Marín et al. 2019). The critical issue of the palimpsest relevance has been more specifically approached by refitting analysis of lithics and faunal remains and spatial analysis (Henry 2012) in order to reconstruct the archaeological assemblage formation from a spatio-temporal perspective. Quantitative approaches, particularly using geostatistical tools, have recently provided a more refined analysis of human occupational patterns (Romagnoli and Vaquero 2016; Gabucio et al. 2018; Marín et al. 2019)

Previous interdisciplinary studies on the Maras 4.1 archaeological assemblage have provided solid data to recognize distinctive events of short-term and specialized occupation (Moncel et al. 2010, 2014; Hardy et al. 2013, 2020; Vettese 2014, Richard et al. 2015; Vettese et al. 2017; Daujeard et al. 2019a). The combination of zooarchaeological, cementochronological and tooth microwear analyses reveals a single-species dominated spectrum, with catastrophic mortality and repeated autumnal deaths during a cold and humid phase of MIS 3. This integrated approach points to short-term hunting episodes of reindeer herds. The technological analysis strategies indicate the fragmentation of the reduction processes in a local and semilocal perimeter around the cave. The lithic procurement shows a flexible Neanderthal strategy combining forethought and planning. Results on micro-wear traces and residues point to mainly non-specialized activities. Considering the abundance of flint sources in the area, Neanderthal mobility appears to have been organized around the procurement of other important resources, including fauna and plants for food or tools as well.

Our objective here is to apply an integrated approach to the lithic and faunal materials based on refitting and spatial distribution in order to more fully understand the behaviours, activities and duration of the occupations of late Neanderthals in south-eastern France. We intend to interrogate our previously proposed circulating model of regional mobility that strongly depended upon a detailed knowledge of the regional micro-topography and the seasonally available resources (Daujeard and Moncel 2010; Moncel and Daujeard 2012; Daujeard et al. 2012; Daujeard et al. 2016). We also aim to challenge our initial hypothesis of reindeer mass hunting strategies (Daujeard et al. 2019a), in order to refine our interpretation of the site function for the level 4.1 occupation phase.

This should also help us to better understand the topographical constraints of this widely opened shelter adjacent to a small, narrow valley on the types of occupation, their spatial pattern and their duration in comparison to other examples of short-term Middle Paleolithic occupation (i.e. Vallverdú et al. 2005; Costamagno et al 2006; Hovers et al. 2011; Sánchez-Hernández et al. 2014; Bargalló et al. 2016; 2020; Castel et al. 2017; Villaverde et al. 2017; Mallol et al. 2019; Real et al. 2019; Mora Torcal et al. 2020; Picin et al. 2020; Bargalló et al. 2020).

Moreover, the chronological attribution of the level 4.1 at the beginning of the MIS 3 between $46 \pm 3$ ka and $40 \pm 3$ ka (Richard et al. 2015) places the occupation among the most recent Neanderthal occupations in Western Europe (Higham et al. 2014). The Abri du Maras is not isolated in the area and it is close to other late Middle Palaeolithic occupations, such as Le Figuier, Mandrin Cave (Vandevelde et al. 2017), Baume Néron (Defleur et al. 1994), Saint Marcel (Moncel et al. 2008; Szmidt et al., 2010) and Abri des Pêcheurs. 
Likewise, the nearby Chauvet cave with its Aurignacian painting attests to the presence of Modern Humans in the region at 32-36 ka (Nomade et al. 2016). It is now well established that the replacement of Neanderthal by Modern Humans between 50 and 40 ka was characterized by a regionalization of lithic traditions, as shown for instance by various "transitional industries". Technological strategies and land use patterns varied greatly in different regions (Quina/Levallois technologies for instance in southwestern France (Delagnes and Rendu 2011, Rendu et al. 2012), or "bout coupé" in England (Ruebens and Wragg Sykes 2016). Therefore, the level 4.1 from the Abri du Maras site could provide one of the latest traces of Neanderthals in the area.

\section{The Abri du Maras site and the level 4.1}

\subsection{The site}

The site of Abri du Maras (170 m a.s.I.) is located on the right bank of the Middle Rhône Valley (Fig. 1), in a small dry valley of the Ardèche River, at the outer edge of the gorges. This rockshelter opens to the southeast and is the relict of a large cave at the end of the small valley (Debard 1988; Moncel et al. 2010, 2015).

The first archaeological investigations at Abri du Maras revealed a stratigraphic sequence of about $3 \mathrm{~m}$ including eight levels with Middle Palaeolithic deposits and a Levallois laminar debitage (upper part of the sequence, level 1) (Gilles 1950; Combier 1967; Debard 1988; Moncel et al. 1994). The new excavations that started in 2006 have since provided a wide exposure of the succession of occupation layers. The excavations were conducted with classical methodologies, using a square meter grid and plotting each object with a total station. A GIS database recorded the spatial distribution (vertical and horizontal) information. Sediments were regularly dry and wet screened for microvertebrates, micro-flakes and shells.

The new excavations include the middle and lower parts of the sequence partially excavated during past fieldwork (previously assigned levels 4 to 8). Six large units or layers have been identified but their relationship with previously assigned levels is unclear due to loss of overlying infill. Stratigraphic layers 6 and 5 are at present the oldest units currently known. They lie on the limestone substratum, visible on different parts of the excavated areas far from the actual shelter overhang. The overlying layer 4 is a 0.5 to 1 $\mathrm{m}$ thick, silty to sandy-silty loessic deposit, mostly of aeolian origin. The coarse components come from frost shattering and gravitational fall of the limestone walls of the rock shelter. The loessic fine fraction originates primarily from the wind erosion of the fluvio-glacial terraces of the Middle Rhône valley during the cold and dry conditions of MIS 3 (Puaud et al. 2015). The initial loessic deposits have been weakly affected by gentle runoff and pedogenic transformations that are essentially expressed by an intense earthworm bioturbation and moderate redistribution of calcium carbonate along root channels (Puaud et al. 2015). The excavation has revealed the occurrence of two archaeological levels, 4.2 and 4.1, clearly separated by a sterile loessic layer, which have been exposed over $50 \mathrm{~m}^{2}$ in the front of the remaining shelter (Moncel et al. 2014). The two distinctive occupation phases both have a high density of artefacts, the lack of in situ combustion evidence, the occurrence of patchy greyish to reddish-brown microaggregate lenses that have been suspected to be hearth remains during the excavation. Rare artefacts have been encountered in the overlying layers $(3,2$, and 1$)$. U/Th dating applied to bones from the top of unit $5 /$ bottom of layer 4 yielded ages of $72 \pm 3 \mathrm{ka}, 87 \pm 5 \mathrm{ka}, 89 \pm 4 \mathrm{ka}$, and $91 \pm 4 \mathrm{ka}$ (Moncel et al. 1994; Moncel and Michel 2000). New preliminary ESR-U/Th dating of ungulate teeth confirmed the chronology of layer 5 ( $90 \pm 9 \mathrm{ka}$ ) but gave more recent ages for layer 4 , attributed at the most to MIS 3 . At present, the upper part of layer 4 defined as level 4.1 can be framed between $46 \pm 3 \mathrm{ka}(n=2)$ and $40 \pm 3 \mathrm{ka}$, while 4.2 level would range from $55 \pm 2 \mathrm{ka}$ $(n=3)$ to $42 \pm 3 \mathrm{ka}$, therefore both belonging to the MIS 3 (Richard et al. 2015). This chronological attribution is consistent with Heinrich events $\mathrm{H} 5$ and $\mathrm{H} 4$, correlated to the $\mathrm{D}-\mathrm{O} \# 12$ event, a record in the Villars speleothems (Genty et al. 2010) of a woody steppe with a relatively warm and humid climate in contrast to the earlier periods.

\subsection{Layer 4 and level 4.1}


At the upper part of the large layer 4 , the excavation of sub-level $4.1\left(34 \mathrm{~m}^{2}\right.$ surface) (Fig. 2, 3) exposed a excavation has not revealed the occurrence of any significant change in colour, structure or texture that would be closely associated with the occurrence of the archaeological items, emphasizing the homogeneity of the clayey-sandy silt sedimentary matrix (see Fig. S1). The accumulation of the archaeological materials was observed to correlate with increased amount of coarse components issued from the pedogenic weathering of the limestone cliff together with the presence of collapsed limestone slabs for levels 4.1 and 4.2. This repeated joint occurrence has allowed us to associate each phase of human presence with specific environmental conditions that were favourable to vegetation colonization of the limestone cliff and soil development on the uppermost limestone plateau.

In contrast, the fine silt texture typical of intact aeolian dust, the weak effect of pedogenesis and the lack of coarse limestone fraction in the sterile deposit that accumulated between 4.1 and 4.2 levels indicates that the site was not occupied when the climate was colder and drier. Microvertebrate remains, and pollen grains are very rare at the site due to poor preservation, whereas charcoals are commonly encountered throughout the two occupation layers showing in general a good preservation independently of a highly variable abundance. The number of charcoal fragments in level 4.1 is low with a dominance of Pinus sylvestris type and Betula sp. (Daujeard et al. 2019a). A lack of preferential orientation of the archaeological materials, confirmed by statistical tests on the trends in orientation of the materials shows the minimal effect of post-depositional processes (Fig. S2). Moreover, the occurrence of some herbivore bones found in close anatomical association, with no evidence of post-fragmentation and broken bones in situ by postdepositional factors, along with the abundance of small lithic and faunal microremains $(\leq 1 \mathrm{~cm}) \mathrm{confirm}$ the very low impact of post-depositional processes (Fig. $\mathbf{3}$ ).

\subsubsection{The faunal assemblage of level 4.1}

The small and large mammal assemblage that is dominated by reindeer ( $88 \%$ of the NISP, representing 16 individuals) with a minor occurrence of horse, bison, giant deer, red deer, ibex and lagomorphs, highlights open landscapes under cold and arid climate. There are no carnivore remains (Daujeard et al. 2019a).

For reindeer, long bones largely dominate the accumulation and, among them, the richest elements in meat and marrow, indicate primary carcass processing on the kill site with subsequent selective transport of the carcass elements. The scarcity of the axial skeleton and of the limb extremities is interpreted as abandonment at the kill site and/or an in situ differential and/or spatial preservation or treatment of spongy bones (bone grease extraction). Presence of cut and percussion marks on the remains of all types of species indicates that all the steps of the carcass treatment were processed in situ: skinning, dismembering and removing tendons, periosteum, flesh, marrow and possibly bone grease extraction.

The high number of reindeer individuals, catastrophic mortality profile, restricted season of death and intensive butchery may correspond with a planned mass hunting strategy of a particular species, with repeated autumnal deaths. The zooarchaeological data highlight diverse subsistence activities managed at the site, including the use of bones for fuel, with the high rates of carbonised bone fragments (majority less than $25 \mathrm{~mm}$ long) and the in situ consumption of meat and marrow. The presence of non-specialised activities differs from other Neanderthal reindeer-dominated assemblages, often connected with specialised sites such as hunting camps, with evidence of food storage and no or scant use of fire, i.e. Salzgitter-Lebenstedt (Gaudzinski and Roebroeks 2000; Gaudzinski-Windheuser, 2006), Pech de I'Azé IV (Niven 2013), Jonzac (Niven et al. 2012), Roc de Marsal (Castel et al. 2017) and Les Pradelles (Costamagno et al. 2006). Here, the data rather suggest the recurrent use of the site as a dwelling camp.

\subsubsection{The lithic assemblage of level 4.1}

The lithic material in level 4.1 totals 2041 items (excavations from 2006-2018 seasons) (Table 1, Tables S1S4, Fig. S2). The applied technical strategies indicate the fragmentation of the "chaîne opératoire" into local and semi-local perimeters around the site (i.e. Moncel et al. 2014). Flint is the main raw material followed by quartz and occasionally basalt, limestone, granite, sandstone, quartzite and schist. The assemblage is 
mainly composed of flakes and fragments of flakes, including $4.3 \%$ Levallois flakes $(n=88)$. Laminar products (blades and bladelets) total 208 pieces $(10.2 \%)$, including 58 Levallois blades. Points total 81 pieces (3.9\%), including some clear Levallois points $(n=44)$. There are 51 cores $(2.5 \%)$, Levallois, discoidal-type, on flake and others. Only 22 cores can be related to the Levallois concept (preferential flake, unipolar convergent removals for points and centripetal). The other cores are unifacial unipolar, discoid, Kombewa, trifacial, orthogonal or crude. Most of them are not exhausted. The original form is possibly a flake for some of them, and for the others a nodule, a pebble, a fragment of slab or undetermined.

Pebble tools are rare (one in quartz), while we total 32 entire or broken pebbles in various stones. Flake tools are rare as well $(n=46,1.1 \%)$. They are mainly scrapers and denticulates, including one Quina scraper made on a thick and large flint flake. Levallois products are not retouched.

The presence of cortical products (both backed and unbacked) suggests that a part of the debitage has been performed on the site with an introduction of already prepared cores. This is also the case for the blades with both cortical and non-cortical blades and points (Fig. 4). There are also backed blades and bladelets. If we compare the ratio of blades and points, there is an over-representation of these products compared to cores. Cores are mainly smaller and few exhausted on nodules or flakes except the Levallois and some centripetal cores made on flakes. A deep reduction would be necessary to be flaked again. The largest products could not be produced on the site and any large by-products are present.

The largest flint flakes, Levallois blades (both cortical and non-cortical, mainly with unipolar schemes) and points were produced elsewhere, to the north and south of the site (up to 20-30 kmand then brought to the shelter (Fig. 4). We total 55 pieces between 60 and $105 \mathrm{~mm}$ long (25 blades, 20 flakes and 10 points). According to geological analysis applied to a sample of more than 200 pieces, 13 raw material types were identified, with several types still unknown. They may have been collected from the Rhône Valley coming from the Alps Mountains. The main flint types so far identified attest to: (1) flint procurement on the plateau to the north of the site at a distance of 3 to $30 \mathrm{~km}$ (local to semi-local Barremian formations) from secondary flint outcrops and conglomerates, (2) secondary collection to the south, on a plateau located between 2 and $20 \mathrm{~km}$ from the site, involving crossing the Ardèche River (Ludian and Lutecian formations). The diversity of types is due to frequent gathering from conglomerates and indicates the indiscriminate use of all kinds of existing flint in each outcrop. Neanderthals collected flint while performing other activities, in a perimeter of $30 \mathrm{~km}$ around the site as an anticipation of future domestic needs.

In terms of tool use, evidence of impact fractures suggests that some points, blades and flakes, could have been used as projectile tips, possibly as part of a complex projectile system (Hardy et al. 2013). Neanderthals exploited a wide range of resources including large mammals, fish, birds (possibly waterfowl and raptors), rabbits, plants, wood, and possibly mushrooms. Twisted fibres on stone tools provide evidence of making string or cordage (Hardy et al. 2020). Most of the stone tools were used for cutting, whatever their size and shape (including the Quina scraper). Imported artefacts and artefacts made on the site were used for the same range of activities and materials (butchery, plant and woodworking - Moncel et al. 2014).

\section{Materials and methods}

\subsection{Contextual stratigraphic analysis}

This methodology focuses on the attributes of the sedimentary matrix immediately associated with the artefacts in order to examine the three-dimensional spatial relationships among objects and deposits (Goldberg and Berna 2009). The aim is to identify at the finest scales the stratigraphic reality of human occupation episodes of level 4.1 with their distinctive microfacies assemblage resulting from the interference of depositional events and anthropic activities (Courty 2001). **

As previously debated (Daujeard et al. 2019a), the contrast between the homogeneity at macroscale of the level 4.1 and the dense accumulations of archaeological remains makes interpreting the imprints of human occupation on the sedimentary matrix difficult. Also, the common occurrence of burnt bone fragments and the abundance of dispersed charcoals but no evidence of in situ heating makes a link occupation with firerelated activities unclear. The occurrence of greyish to reddish-brown thin lenses contrasting from the embedding loessic sediment by their granular structure were suspected to be possible remains of 
combustion deposits (Daujeard et al. 2019a). This suggested that the level 4.1 homogeneity could either express weak impact of human activities on the host sediment during short occupation events or complete alteration of anthropic attributes by post-depositional processes. In the absence of a distinctive microstratification throughout level 4.1 or of clear living-floors, contextual stratigraphic analysis was performed in the field by testing the link between any noticeable changes of microfacies and the occurrence of human artefacts. All subtle variations of microfacies identified by contrasting structure, texture or colour from the homogeneous host sediment have been exhaustively sampled to perform a systematic analysis of the microresidues from the bulk sediment samples. A sample of bulk matrix has also been systematically collected with each burnt bone or charcoal fragment that was exposed during the excavation. The same strategy was adopted for the polymer compounds that are similar to the previously identified ones in similar Neanderthal contexts (Courty et al. 2012). The polymer films, filaments and aggregates were identified with the naked eye during the excavation wihtint heir host matrix. . The exposure in square 16 of a $5 \mathrm{~cm}$ thick microstratified sublayer showing a succession of three greyish brown microaggregate lenses interwoven with abundant humified plant fragments and layered faunal remains with anatomical connections has provided a unique chance to perform a high resolution microfacies analysis during the excavation (Fig. 5).

At an early stage of the excavation, a continuous column of undisturbed sediment blocks was sampled in a benchmark section for the fabrication of thin sections for micromorphological study. The column sampling was performed in an area with low density of human artifacts.

All the bulk samples collected along the course of the excavation were water-sieved to obtain the total dispersion of the weakly resistant aggregates, clean grain surfaces and separation by sized-fractions ( $>2 \mathrm{~mm}$, 2-1 mm, 1mm-500 $\mu \mathrm{m}, 500-250 \mu \mathrm{m}, 250-100 \mu \mathrm{m})$ after separation of light components by flotation. A morphological and mineralogical classification of the water-sieved residues was performed under the binocular microscope in order to perform a microfacies analysis of layer 4.1 and to identify unusual elementswhich would contrast from the bulk components. A selection of these unusual elements was subjected to scanning electron microscope and microprobe analyses (SEM-EDS).

\subsection{Spatial pattern analysis}

Level 4.1 is possibly a palimpsest of several occupations. The density and thickness of the material (Moncel and Daujeard 2012; Daujeard et al. 2019a). makes it difficult to distinguish all occupational events and the intensity or duration of each one (i.e. Mora Torcal et al. 2020). Based on previous results of archaeological assemblage studies, we decided to test spatial patterning focused on the horizontal distribution of all the remains from level 4.1 (Moncel et al., 2014; Daujeard et al. 2019a). The spatial patterning of the lithic and faunal remains is then compared with the data from lithic and faunal refitting and RMU lithic analysis (Bargalló et al. 2016; 2020; Romagnoli and Vaquero 2019; Fernández-Laso et al. 2020; Spagnolo et al. 2020a, 2020b). These analyses provide insight into some spatial behaviours of Neanderthal groups occupying the rock shelter. Moreover, they provide a key to improving our knowledge of their cultural capabilities (Vaquero and Pastó 2001). However, given the limited extent of currently excavated surface, the analyses do not consider the entire area occupied by Neanderthals at the site. GIS analysis was carried out using ArcGIS 10 software (ArcMap 10.4) (ESRI 2014). Nearest Neighbour Analysis and Kernel density analyses were used to identify the distribution pattern statically and visually. The research radius in the Kernel density analysis was defined as half standard deviation of our data.

\subsection{Faunal refits}

Bone fragments are less often included in refitting program than lithic materials. However, to discuss both the synchronic and diachronic components of transport and carcass processing events, bone refitting is essential (Rosell et al. 2012, 2019; Bargalló et al. 2016; Romagnoli and Vaquero 2019). Faunal remain refitting is one of the last steps of the zooarchaeological analyses, after taxonomic and anatomical determinations and taphonomic studies and can aid in the understanding of the taphonomic dynamics of the assemblage. Bone refitting can be complex because of species diversity within faunal assemblages and the quantity of bone fragments. Furthermore, material weakness increased the post-depositional fragmentation which may add to the perimortem fragmentation (Poplin 1976; Soulier 2013). 
All the three-dimensionally recorded archaeological remains $(n=1946)$ and the $\leq 1-1.5 \mathrm{~cm}$ material nonrecorded collected by sieving $(n=242)$ are taken into account.

In our work, mechanical and anatomical refitting (articulation and bilateral pairs) focused mostly on long bones and teeth of large- and medium-size ungulates (Morín et al. 2005; Lyman 2008; Enloe 2010; Férnandez-Laso 2010). Spongy undetermined fragments were excluded in systematic refitting but undetermined shaft fragments $(\geq 2 \mathrm{~cm})$ were included. Green bone or dry bone fracture edges help determine the homogeneity of assemblages through the identification of the in situ fragment movements (vertically and horizontally, intra- and inter-levels) (Enloe and David 1989; Villa and Mahieu 1991). Some refits were found during zooarchaeological analyses while other were notices during excavation. However, due to the scarcity of the long bone epiphyses and other elements of axial skeleton and carpals and tarsal, the anatomical refitting yielded few results compared to mechanical refitting, especially the bilateral pairs, which is quite impossible to identify in archaeological context. The identification of refits and anatomical connections during the excavation of level 4.1 revealed a weak pre- and post-depositional spatial disturbance of the archaeological material and offered us the possibility of distinguishing possible areas of activity (Rosell et al. 2012, 2019; Vettese 2014). Due to these numerous refits and the good spatial conservation of the elements, we established a systematic refit protocol for the long bones of Level 4.1 (Vettese 2014, Vettese et al., 2017; Daujeard et al. 2019a):

(1) Selection and sorting of the identified remains by anatomical parts (ex. humerus, radio-ulna...taking account all the remains $\geq 2 \mathrm{~cm}$ );

(2) Sorting by portions and sides (anterior, medial, posterior and lateral) (Fig. 2, Vettese et al. 2017);

(3) Classification of all the remains by lateral side (right, left or undetermined);

(4) Comparison of all the remains between right and left side and also with the undetermined ones, square by square and between squares;

(5) Spatial distribution analysis of the bone refits and connections to identify the fauna-linked activity areas;

(6) Cross-comparisons with the lithic refits and other disciplines in order to reach a comprehensive view on the type of occupation based on multiple resources.

\subsection{Lithic Raw Material Units (RMU) and refit lithic analysis}

The Raw Material Units (RMU) and the refit analysis allowed the reconstruction of the temporal formation of the lithic assemblage and identification of specific events of technical activity. This is defined as an activity episode related to the manipulation of lithic resources that is performed continuously, without location changes or temporal interruption (Roebroeks 1988; Vaquero 2008).

Refits are the most direct evidence to identify pieces belonging to the same RMU. However, other kinds of data must be considered. First, the macroscopic characteristics of the raw materials, including colour, grain, size, texture, inclusions and type of cortex. The technical categories, the size of the pieces, together with their spatial pattern are also used to integrate different artefacts in the same RMU (Machado et al. 2011, 2013; Vaquero et al. 2012a, 2012b; Chacón et al. 2015). In addition, RMU have been characterized by considering two main features: introducing events defined by the mode of introduction and knapping events referring to the intentional modification performed inside the site. We have also used petrographic analysis to group some RMUs on patinated flint due to the very high percentage of patinated flint material (around $58 \%$ ) in level 4.1 (Moncel et al. 2014).

For the refit analysis, we used the methods and terminology proposed by Cziesla (1990) and Sisk and Shea (2008). This methodology has been already used in other Middle Paleolithic sites with very good results to reconstruct the formation and composition of the lithic assemblages (among others: El Salt, Abric del Pastor, Abric Romaní, Teixoneres cave - Roebroeks 1988; Vaquero 2008; Chacón et al. 2015; Machado et al. 2011, 2013, 2019; Vaquero et al. 2012a, 2012b, 2019; Picin et al. 2020).

Three kinds of connections are distinguished: production-sequence, breakage and retouch refits. For production and retouch refits, connection lines have been defined according to the chronological order of 
detachments, starting with the first refitted flake to the core or tool. For the refits of broken artefacts, the connection lines have been established by considering the contacting surface (Vaquero et al. 2012b). The refitting procedure allows us to distinguish two formingprocesses: (1) sets of artefacts splitting from each other by controlled conchoidal fracture (e.g., a flake whose ventral side joins to the surface of a core or the dorsal surface of another flake); and (2) conjoins: fragments of artefacts broken by forces other than conchoidal fractures (e.g., natural flaws, bending fractures, burning, etc.) (Sisk and Shea 2008).

A total of 2050 lithic items recorded for level 4.1 were considered for this study, discarding the badly preserved pieces (with patina or thermal alteration) and pieces $\leq 1 \mathrm{~cm}$ long. The amount is not the same that in Table 1 ( $n=2041)$ because some microflakes from the sieving materials were identified as parts of RMUs due to their macroscopic attributes.

As a final step for the faunal and lithic refits, their spatial distribution together with the one of the RMU groups has been analysed. The results obtained are interpreted by integrating the multidisciplinary analysis of the different resources in order to identify the activity events (technical or related to the exploitation of carcasses) and their relevance in terms of occupation type for level 4.1.

\section{Results and interpretation}

\subsection{Contextual stratigraphic analysis}

The micromorphological study performed on the benchmark section covering the entire level 4.1 confirms its homogeneity throughout the $20 \mathrm{~cm}$ thick deposit with a well-developed biogenic microstructure showing dense packing of earthworm pellets. The absence of distinctive vertical channels and the uniform composition of the microaggregated fine mass indicate an accumulation of biogenic reworked soil-materials rather than post-depositional effects of bioturbation. This extensive deposition of previously bioturbated soil-materials suggests that the limestone cliff was extensively colonized by woody vegetation with dense roots that trapped the loessic sediment. Incipient in situ redistribution of secondary carbonates along the packing porosity of the biogenic microaggregates has acted as a weak cementing agent of the deposits, thus favouring their intact preservation following their accumulation at the surface. In addition to the major silt component of aeolian origin, level 4.1 also displays an abundant subrounded calcareous coarse fraction (20 to $40 \%$ ) of local origin and a minor population of angular quartz fine sands. The surface corrosion of the local coarse components that is typical of the microbial weathering occurring in root-colonized soil materials contrasts with the fresh angular sands, thus suggesting a possible exogenous origin. The random distribution of the limestone components and the lack of any freeze-thaw pedofeatures in the fine mass indicate that level 4.1 did not suffer from significant effects of frost during its accumulation.

These microstructural characteristics are coherent with the close association of the archaeological materials with the large slabs that collapsed from the limestone walls and partially fragmented in situ due to weathering by root colonization, as noticed during the excavation. The formation of level 4.1 can thus be concluded to have occurred under a mild temperate climate that allowed the formation of a dense vegetation cover protecting the limestone cliff from the direct effect of rainfall thus offering a dry shelter to the occupants. In contrast, the fine silt texture, the weak effect of pedogenesis and the lack of coarse limestone fraction in the sterile loessic deposits that bracket level 4.1 indicates that the site was not occupied when the limestone cliff was no longer protected by a dense vegetation cover and therefore directly exposed to winds and rainfall.

A few diffuse, $\mathrm{cm}$-thick discontinuities that are marked by a more open micro-aggregation have been identified in the thin sections. These have sub-horizontal biochannels, well-preserved humidified organicfragments, slight depletion of the calcitic fine mass and of the coarse fraction, and higher abundance of the angular quartz sands. This particular microfacies is typical of soil surface that was covered for a while by 
biogenic crusts most probably due to moisture increase, thus inducing microbial activity (Courty et al. 1989). However, the scarcity of microartefacts (bone and charred residues) and the absence of a distinctive trampled-linked microstructure do not allow us to consider these subtle discontinuities as residual living floors (Gé et al. 1993).

These discontinuities differ from the greyish to reddish-brown microaggregate lenses by their diffuse characteristics and the lack of distinctive attributes for relating them to human activities.

In contrast, the greyish to reddish-brown microaggregate lenses have been clearly identified in the field along the course of excavation by their sharp contact with the host homogeneous sediment, their loose microstructure and the common occurrence of microartefacts (Fig.5a, b).

Their microfacies analysis reveals a dense packing of coarser aggregates ( $5 \mathrm{~mm}$ in average) that have a high structural stability and a marked hydrophobicity as compared to the homogeneous level 4.1. A great diversity of abundant millimetre-sized microresidues with clean, hydrophobic surfaces have been retrieved from the fine mass (Fig.6a). They comprise a high amount of the angular quartz sands that are similar to the ones in the weak discontinuities, along with abundant polymer components, siliceous sandstones, glassy breccia, metal films, fine charcoal, vitreous chars, shell fragments, flint micro-flakes, humified plant fragments, whitish ash grains, burnt, calcined or pyrolyzed bone fragments and elements of flying insects.

The analysis of the water-sieved residues from the matrix associated with charcoals and chars that were collected throughout level 4.1 revealed similar translucent polymer films and coloured filaments, often in the form of twisted bundles.

Within these diverse microresidues, the SEM-EDS analyses showed a common occurrence of nanostructured deposits of native metals which are either filling micro-cavities, forming aligned droplets, or being attached as twisted films to vesicles of the microdebris (Fig.6). All these exotic components have been previously identified in Neanderthal hearths at the Abric Romani (Courty et al. 2012) and have been since shown to be traces of flash-pyrolysis by-products that are issued from lightning-triggered aerosol transformation during periods of enhanced atmospheric electrification (Courty 2017). The occurrence of these flash pyrolysis by-products in the chars and charcoals of level 4.1 indicates the use of wood fuel that accumulated lightning-formed refractory components of enhanced conductivity in the plant tissues during tree growth (Courty et al. 2020).

The microfacies of the microaggregate lenses with their heteroclite microresidues does not match any type of firing by-products which have been encountered so far in present or past fires of human or natural origin (Courty et al. 1989; Courty 2012; Macphail and Goldberg 2018). Furthermore, only part of the microresidues displays burning traces whereas other are unburnt, although showing metal encrustations. In addition, the sharp contact of these distinctive microfacies with the surrounding and underlying sediment and the lack of large earthworm channels indicate that the microaggregation was not formed by in situ reworking of combustion deposits. In contrast to the adjacent bioturbated matrix of level 4.1, the abundance of human-related microresidues refutes an origin of soil materials falling from the limestone cliff. Therefore, the microaggregate microfacies must be an earth-made anthropogenic material mixed with fire residues and lightning-formed organo-mineral components. The observation during the laboratory treatment by moderate heating at $80^{\circ} \mathrm{C}$ of a new generation of sticky polymer films bounding the watersieved residues showed that active catalyzers are still present in the microaggregates and are still reactive. Similar kinds of highly reactive catalyzers have been observed in recent situations of lightning impact at the ground along to highly stable polymers and metal pulverisation (Courty 2017; Courty et al. 2020). Compared to the reference data base, their great abundance in the microaggregate lenses of level 4.1 at the Abri du Maras helps to establish their anthropogenic deposition from use of lightning-impacted organic materials. This correlation is confirmed by the good match between the vertical distribution of the archaeological objects and the depth of the microaggregate lenses shown by the archeostratigraphic profiles.

The contextual stratigraphic analysis of level 4.1 provides solid support to establish the multiplicity of occupation episodes for a short duration, which coincides with periods of enhanced lightning in response to atmospheric increase of ionized aerosols (Courty 2017; Courty et al. 2020). The absence of a continuous 
particle-size range between the coarse and fine components of the artefacts clearly shows the lack of mechanical fragmentation which would have been caused by intense trampling of long-used surfaces. This moderate mechanical effects of human activity is confirmed by the microstructural properties of the successive level 4.1 occupation phases. The weak anthropogenic impact associated with the abundance of lightning-related microresidues suggests that the successive short-time occupation episodes share in common a set of activities linked to the use of lightning products.

The highest density of lithic remains in the main part of the excavated area indicates that the occupations were preferentially located at a certain distance from the shelter wall, probably at the edge of the shelter roof (Fig. 7). As suggested by Combier (1967) and Debard (1988), at the time of level 4.1 deposition, the shelter was already largely collapsed and therefore limited to the right side of the small valley. There is no clear concentration of artefacts within the site, except a higher density of lithic remains close to the areas with the microaggregate greyish to brown-reddish lenses at the Northeast part and at the centre of the excavated area.

\subsection{Spatial patterning}

Level 4.1 has been excavated over a surface of $34 \mathrm{~m}^{2}$ and a total thickness of $20 \mathrm{~cm}$. Due to the dense accumulation of archaeological remains over the entire surface, it was presumed that level 4.1 did not present well preserved living floors (Daujeard et al. 2019a, b). After the study of the total archaeological assemblage (fauna, lithics and others; Fig. S4-8) from different methodological approaches, we decided to apply some spatial geostatistics in order to identify, from a quantitative point of view, the possible existence of accumulation areas that could correspond with domestic activity areas (following the definition of Stevenson 1991; Vaquero and Pastó 2001).

The Nearest Neighbour Analyses of all the remains, including faunal and lithic materials, show that the spatial distribution is significantly clustered (all: score z: -55.38, p-value<0.001; bone: z-score: $-40.33, \mathrm{p}$ value<0.001; lithic: $z$-score: -31.04 , $p$-value<0.001). To visualize the clusters, we applied a Kernel-density analysis and the results show some clear accumulations of remains. These clusters are associated with the higher density of archaeological remains (fauna and lithics) and the microaggregate greyish to brownreddish lenses (Fig. 8). The general pattern of level 4.1 shows four main accumulations areas (A to D) and three secondary ones ( $E$ to $G$ ), whereas the other remains are dispersed throughout the entire occupied surface. Some remains dispersed within the first interval (0-7\%, lower concentration of remains) were located on the areas with few artefacts present, possibly in sectors where the level is residual.

The spatial patterning of the faunal (Fig. 9) and lithic remains (Fig. 10 and 11) shows significant differences despite a broadly similar general distribution. The lithics show a larger dispersion of remains (from lines 5 to 8 ) that the faunal ones (from lines 5 to 7). Thus, a greater quantity of artefacts was produced by knapping activities than the exploitation of carcasses and their normal dispersion is usually $\leq 1.5-2 \mathrm{~m}$ around the knapping locations (see refits section). In addition, the lithics present a higher number of clusters than for the faunal remains, especially for the main largest/dense accumulations areas (Fig. 8).

Lithic refits show pieces that connect two accumulations ( $n=7$ refits) whereas faunal refits show only one (see section 4.3 and 4.4.2 - Fig. 9 and 11).

Considering the general distribution of the remains and the morphology of the shelter over time, the main activities areas that are now identified are located just at the centre towards the outside part of the site. The geological study and the previous excavations showed that the slanted topography of the limestone substratum with a series of steps encouraged the occupants to settle a bit far from the shelter wall (Combier 1967). Therefore, the successive occupations followed the shortening of the roof in order to always settle at the best place, some meters away from the shelter wall. This open, well-lit area was also conducive to subsistence activities. This pattern is similar to the ones found in other Middle Paleolithic sites and can also be found in numerous ethnographic accounts (Binford 1978, 1996; Henry et al. 1996, 2004; 
O'Connell 1987; Stevenson 1991; De la Torre et al. 2012; Modolo et al. 2015; Ekshtain et al. 2019; Fernández-Laso et al. 2020; Spagnolo et al. 2020a, 2020b).

\subsection{Bone refits}

Based on 2188 remains analysed, we identified 222 remains (10\%), split into 88 bone refits in level 4.1 . Mechanical refits represent the most frequent type, with 46 green bone fracture refits and 21 dry bone fracture refits, whereas there were only 21 anatomical refits. The most numerous refits are those composed of 2 remains ( $n=64$ refits), followed by 3 remains ( $n=13$ refits). Refit groups with more remains (between 3 and 8 ) are less frequent ( $n=11$ refits) (Table 2 ). The longest refit is anatomical and connects eight elements (including seven complete ones).

Regarding all refits, 134 connection lines were identified (anatomical refits $(n=47)$, green bone fracture refits $(n=62)$, dry bone fracture refits $(n=25))$. The longest distance recorded was 2.51 meters for a green bone fracture connecting two bones (Table 3). However, the distance of most of the remains refitted was equal to 0 ( $52 \%$ of the refits).

At taxonomic level, Rangifer tarandus showed the largest number of refits (61 refits) incorporating 547 remains (Table 4), reflecting its dominance at the site. Equus ferus was the next most common with a majority of anatomical refits (3/6). We also found refits of non-taxonomically identified elements (20.5\%). Most of the bone refits were the partial reconstruction of long bone remains, mostly forelimbs (Table 5). All the bone refit of the head were anatomical refits.

In horizontal distribution, the bone material followed the pattern observed with the clusters resulted of the analysis of all the remains. However, areas $C$ and $D$ are grouped together. Most of the refits are in the main cluster areas defined from the Kernel density (Fig. $\mathbf{8}$ and 9). These zones are not connected, except for one mechanical refit, a green bone fracture, connecting the main area $\mathrm{D}$ with the secondary area $\mathrm{E}$.

\subsection{RMU and lithic refits}

As we previously mentioned (see materials and method section), the percentage of patinated flint material for level 4.1 is high (around $58 \%$ ). A total of 2050 lithic items were considered for this study. Patinated, thermally altered, and pieces $\leq 1 \mathrm{~cm}$ long were excluded from this study. Nevertheless $52 \mathrm{RMU}$ and 22 refitting groups were recognized.

\subsubsection{RMU analysis}

The 52 RMU identified total 593 pieces ( $26.3 \%$ of the lithic assemblage, Table 6), mainly in flint and quartz. Each RMU corresponds to individual technical events and they were categorized as representing either introduction to the site (introducing events - IE) or modification performed on the site (knapping events $\mathrm{KE})$.

Some RMUs indicate several complete or almost complete knapping sequences produced on-site. All the technical categories are observed in the same RMU, including the production of the first cortical flakes and the different phases of reduction sequences and cores. Others show the fragmentation of the reduction sequences. The smallest RMUs are composed of a single object (isolated artefacts). These pieces were introduced to the site already knapped and are interpreted as part of tool kits transported by the human groups while moving throughout their territory. These tools demonstrate the fragmentation of some reduction processes and the existence of planned behaviour strategies in relation to (1) raw material constraints and, (2) specific needs in relation to the activities performed within and outside the site. Table 7 synthetizes and describes each identified RMU. 
The IE are mainly knapping products (flakes, blades and points) of different sizes, produced by both Levallois and discoidal strategies (e.g. Isol-FI 1 to 11, Isol-Qtzite 3, Fl-1 - Table 7 and Fig. 10b-d). Some cores are introduced in an advanced state of reduction and are abandoned at the site after yielding a small number of flakes (around 2-3) (e.g. RMU Fl-16b, Table 6).

The KEs demonstrate the co-existence of different core technologies, with a predominance of centripetal bifacial strategies (e.g. RMUs Fl-5b, Fl-13, Fl-16d to f, Qtz-1). Levallois technology only employs flint and limestone with unipolar recurrent and recurrent centripetal methods most common. For other stone types (i.e. quartz) the most frequent methods are orthogonal and discoidal. Nodules, angular fragments and large flakes form the basis of cores.

The high degree of reduction often produces cores that are over-exhausted, making it difficult to identify the method, but the knapping products present the typical attributes necessary to describe the core technologies.

The technological analysis of the whole assemblage (Moncel et al. 2014), as well as the RMUs analysis, shows a high degree of fragmentation of the lithic reduction processes (i.e. Vaquero et al. 2012b; Turq et al. 2013; Vaquero et al. 2012b). Some isolated pieces are introduced to the site already knapped while some RMUs show that the main technical processes were realized on the site. However, some pieces are missing, mainly predetermined flakes and cores (e.g. RMUs Fl-12, Qtz-5). Knapping products and flake tools may therefore be mobile or curated pieces (i.e. Vaquero et al. 2012a, Vaquero et al. 2012b; Moncel et al., 2014; Spagnolo et al. 2020b; Mayor et al. 2020; Picin et al. 2020). By contrast, some RMUs show the entire reduction but not the core, indicating that a core could have been transported away from the site as a new mobile tool kit.

There are many isolated artefacts produced in flint (Table 6 and 7). These pieces are all produced with Levallois technology and are mainly flakes, blades and points. There are some in quartz, quartzite and basalt, with one quartzite piece that looks like a Levallois product. The other artefacts are unretouched flakes or fragments coming from discoidal and orthogonal technologies.

The spatial distribution of the RMUs does not show any special spatial pattern either by RMU,by type of stone or technological composition. Their density and spatial distribution correspond to the pattern observed in the spatial Kernel analysis of the lithic and faunal assemblage (Fig. 8 and 10). Some of them present a normal dispersion of a knapping area (e.g. RMU Fl-12, Fl-15) (Newcomer and Sieveking 1980; Böeda and Pelegrin 1985; Cziesla, 1990 Vaquero et al. 2019), while others are spread over the whole occupation area (e.g. RMU Fl-13, Fl-16). A clear example is the spatial patterning of the RMU Lim-1 (unique RMU in limestone and formed only by Levallois flakes - Table 7 and Fig. 11d) that corresponds with the main and largest accumulation identified by the Kernel analysis as well as for the lithics than the bones. Consequently, this RMU may relate to one specific occupation event. The differences and overlap in RMU spatial patterning support the hypothesis of repeated short-term occupations. (Vaquero et al. 2012; Spagnolo et al. 2016; 2020b).

\subsubsection{Lithic refits analysis}

After the analysis of the RMU, some pieces $<1 \mathrm{~cm}$ long recovered from the sieving material were also taking in account for the refitting.

A total number of 22 refits groups comprising 49 pieces have been identified. The lithic refit rate of the whole lithic assemblage $(n=2050)$ is $2.4 \%$ with $8.2 \%$ coming only from the identified RMU groups ( $n=593$ ). Flint and quartz present the highest number of refits. Most of them are composed of two elements (82\%) and with the largest comprising 4 pieces (Table 8).

The majority are knapping products, mainly flakes and flake fragments. There are only 3 cores and 1 flaketool (Table 9). These products come mainly from Levallois and discoidal strategies (Fig. 11b, 11d-f).

The refits give 27 connections lines (see Table 10). Most of the lines correspond to knapping connections (55.5\%), knapping fractures and conjoins (22.2\% each). Due to the difficulties in refitting, small retouch 
flakes as well as the high number of isolated artefacts carried out to the site already knapped, it was difficult to identify refits related to retouch (Table 10, Fig. 4 and Fig 10c, d). Where refits were possible, knapping connection lines are dominant no matter the stone type. All of them following the same pattern, even if), core reduction activities were carried out in situ (e.g. limestone). The distances of the connection lines vary from several centimeters to almost 4 meters (Table 11). They are within the normal dispersion range observed by experimental archaeology for on-site knapping sequences that are normally less than $1 \mathrm{~m}$ in diameter and rarely exceeding $2 \mathrm{~m}$ (Newcomer and Sieveking 1980; Böeda and Pelegrin 1985; Cziesla, 1990; Vaquero et al. 2019). Most connection lines are shorter than $1 \mathrm{~m}$ $(n=17-63 \%)$, six refits (22.2\%) are between 1 and $2 \mathrm{~m}$, and only 4 (15\%) between 2 and $4 \mathrm{~m}$. The shortest connection lines belong mainly to the conjoins (post-depositional breakages produce by trampling). The longest connections lines are all related to knapping activities with only one refit of 3 pieces (belong to a conjoin) presenting a distance for more than $1.5 \mathrm{~m}$ (Fig. 11). Since in situ preservation of anatomical bone connections and broken artefacts suggests that natural processes have had minimal impact on the site, these longer connections lines suggest intentional anthropogenic movement of some pieces during daily activities,. These pieces were knapped in one area and moved to other part of the settlement and/or abandoned at the place of their last use. These pieces with intra-site mobility are all products of on-site knapping and are not distinguished by a particular raw material type.

The spatial patterning of the lithic refits reveals two clear patterns. First, the refits are clearly located in the main accumulation areas identified by the Kernel analysis (Fig. 11). Second, there is an important number of refits that connect some of the identified clusters (e.g. A with $D, E$ with $D, B$ with $G$ and one between $E, F$ and $B$ ). Consequently, the lithic refits show a higher degree of articulation of the occupied surface than the one observed by the faunal refits (Fig. 9). However, we cannot confirm that these connections between areas are showing their temporal synchronicity, because (1) the unidirectionality patterns of pieces moved and (2) any recycling pattern have been observed in any of these pieces (Vaquero et al. 2015; Romagnoli and Vaquero 2019).

\section{Discussion and conclusion}

The results of this work demonstrate that quantitative approaches, associated with the interdisciplinary empirical processing of data, are suitable and adequate methods for describing the spatio-temporal formation of the archaeological assemblages and can be used to reconstruct human occupation patterns. We identified seven different accumulations areas, all related to subsistence activities and associated with remains related to the use of fire by-products (domestic areas sensu Stevenson 1991; Vaquero and Pastó 2001, Fig. 8), although in situ combustion deposits and structured hearths were not identified. This is also confirmed by the results of the faunal and lithic refits and the RMU analysis (Fig. 10 and 11). Despite the 34 $\mathrm{m}^{2}$ excavated surface we know from the shape of the substratum observed in previous excavations, that the successive occupations followed the shelter ceiling and floor. The oldest occupations are farther from the shelter wall and are located on a lower limestone step.

Level 4.1 of the Abri du Maras provides detailed evidence on the types of occupations under an open shelter during MIS 3. This site reveals some unusual patterns for Middle Palaeolithic short-term occupations (i.e. Sánchez-Hernández et al. 2014; Gabucio et al. 2018; Moncel et al. 2018, 2019; Bargalló et al. 2020; Cascalheira and Picin 2020; Picin et al. 2020). Previous studies have highlighted various types of Neanderthal cave and shelter occupations with a farsighted circulating model and recurrent base camps of various duration, from seasonal camps to bivouacs (Daujeard and Moncel, 2010; Daujeard et al. 2016). Instead, we have intensive in situ carcass processing, non-specialized dwelling activities with evidence of fire use, and no traces of carnivore activity (Hardy et al. 2013; Daujeard et al. 2019a). Furthermore, this study highlights low material displacement, more faunal refits than lithic ones, and a relatively low ratio of flaketools. This pattern is uncommon compared to the other examples of short-term occupations both in the region and in Europe in general.

Short-term occupations are characterized here by the introduction of large with secondary flaking in situ, raw material collection within $30 \mathrm{~km}$ of the, and behaviours organized around the exploitation of the 
surroundings during short-term autumnal reindeer hunting episodes (can be seen in other sites i.e. Costamagno et al. 2006; Richards et al. 2008; Gaudzinski et al. 2009; Daujeard and Moncel 2010; Britton et al. 2011, 2012; Niven et al. 2012; Rendu et al. 2012; Daujeard et al. 2016, 2019b; Discamps and Royer 2016; Discamps and Faivre 2017; Cascalheira and Picin 2020).

Zooarchaeological and taphonomic studies, combined with spatial analyses applied to faunal material (including bone refits), is a useful tool for identifying areas of activity (Vaquero et al. 2012a, 2012b; Rosell et al. 2012, 2019; Spagnolo et al. 2019). Faunal refitting allows us to test the time between carcass processing events. According to our analysis, we observe minor or no displacement of bone remains, with most of the refits having a distance of zero. Anatomical refits demonstrate a high fidelity of spatial distribution. Among the high number of bone refits, most are green bone fractures (Daujeard et al. 2019a). Root-etching alterations are the principal modifying agents of bone surfaces with half of the assemblage presenting more than one-third dissolved surface. However, this did not prevent the identification of numerous refits. The one dry bone fracture with a zero distance could be the consequence of sedimentary compaction without visible hiatus. Together, this shows a high preservation of the spatial integrity of the occupation level with a vertical distribution related to sediment compaction. It highlights the high probability that the level is a palimpsest of several occupations. Almost all the bones (in particular the ones involved in refits) have no traces of weathering, thus suggesting rapid burial. Moreover, we observed very few trampling marks and no carnivore disturbance. This indicated also that the rapid burial of the bone remains. Overall, this suggests that the excavated area has a high temporal resolution.

Most of the faunal refits have a small or a zero distance. Moreover, most of the activity areas identified are not connected by bone refits, except for one green bone fracture refit involving a displacement before the bone dried and before burial. Butchery activity distributions seem to be clustered indicating different carcass processing episodes. All the activities of the butchering "chaîne opératoire" were carried out in situ (Vettese et al 2017; Daujeard et al 2019a). However, the absence of hearth does not allow specifying the hypothesis on the functionality of these areas (toss or drop zones, or activity areas) based on ethnographic observations (Binford 1978, Rosell et al. 2012). Clusters of bone and lithics are quite similar. We also observed some patterning relating possible butchery activities with the microaggregate lenses. Moreover, we noted a scarcity of bone remains around the microaggregate lenses.

The implication of monospecific faunal spectra in late Neanderthal occupation contexts reflect specific behaviors which particularly raises questions regarding food meat and marrow abundance in the case of this specialized hunting strategies (Gaudzinski and Roebroeks 2000; Costamagno et al. 2006; Niven et al. 2012; Niven 2013; Castel et al. 2017). The high frequency of reindeer in level 4.1 shows that Neanderthals used the site in the autumn specifically for this task, targeting the most common species in the area (Gaudzinski and Roebroeks 2000; Costamagno et al. 2006; Niven et al. 2012; Niven 2013; Castel et al. 2017). Moreover, the selective transport of the most nutritionally valuable elements within the rock shelter shows planning and forethought (Vettese et al. 2017; Daujeard et al. 2019a). Intact metapodials with no evidence of butchery suggests a relative abundance of food and relatively short occupations of the site. This is further supported by extensive long bone breakage with little evidence of exploitation of phalanges or mandibles for marrow. The emphasis on bones with large amounts of marrow suggests a period of abundance of meat and marrow. Bone retouchers are absent indicating that bone was not reused after butchery. All this leads to evidence of several rather short occupations that are repeated over time and mostly centered on the reindeer carcass processing.

The technological attributes observed on the RMUs and the refits confirm the preliminary results of the technological analysis of the whole lithic assemblage (Moncel et al. 2014) and emphasize several main features. First, the high degree of fragmentation of the reduction sequences and the high number of isolated artefacts brought to the site already knapped are evidence of planning ahead based on anticipated raw materla constraints and subsistence activities (Kuhn 1992, 1995). Second, the evidence of partial reduction sequences could be interpreted as a feature of repeated short-term occupations in relation to the hunting of reindeer (Turq et al. 2013; Mayor et al. 2020; Picin et al 2020). Moreover, the variability of 
RMUs spatial distribution (see Fig. 10, Table 7) with some more clustered and some more scattered, reflects a series of short term occupations.

The spatial patterning of the archaeological remains and the morphology of the shelter over time shows that the main activities areas that have been so far identified are located in the centre of the excavated area, about 4 meters from the shelter wall. The shelter substratum, with its successive steps, appears to have strongly influenced the location of occupation. The occupations are located in the best area under the roof edge to develop the subsistence activities with more light. This pattern is similar to other Middle Paleolithic sites and ethnographical data. The direct contact of the latest occupation with the limestone substratum at the foot of the shelter wall suggests that part of the sequence has been possibly eroded. The occurrence of the large limestone slabs that collapsed at some distance from the shelter wall appears to have greatly aided in the preservation of the level 4.1 occupational sequence.

The good preservation of anthropogenic microfacies and scattered charcoal fragments throughout level 4.1 , together with the lack of evidence for in situ bioturbation, show that the lack of hearth structures or of distinctive firing deposits is not a bias caused by post-depositional alteration. The profusion of scattered highly fired bones and vitreous chars in an unburnt host matrix suggests that the fire-related residues have been displaced from the original activity area where they were produced and intentionally used for such as other activities, as suggested by the scattered charcoals. The excavated area may not correspond to the particular location devoted to fire maintenance and more likely represents an open well-lit area devoted to subsistence strategies since it is far from the shelter wall (Kedar et al. 2020). Wood was probably the main fuel used (see charcoals of trees collected on the site) and was probably collected from the nearby areas based on the gathering of fallen branches. The selection was based on branch sizes and condition of the wood as has been suggested for other sites (Uzquiano et al. 2012; Solé et al. 2013; Vidal-Matutano et al. 2015; Allué et al. 2017; Vidal-Matutano 2017).

The spatial distribution of the lithic refits reveals two patterns. First, the refits are clearly located to the main accumulation areas identified by the Kernel analysis (Fig. 8). Second, there are a significant number of refits connecting some of the identified clusters (e.g. A with $D, E$ with $D, B$ with $G$ and one between $E, F$ and B). All the faunal refits are well clustered on the accumulation area and only one connect two of them. This faunal refit with a long connection line could suggest possible food sharing between the group's members or different areas of treatment of the carcasses (Gabucio et al. 2018; Marín et al. 2019) (butchery specialized areas). By contrast, the lithic refits show a higher degree of articulation and intra-site mobility in the occupied area ( $n=7$ refits) compared to the faunal refits ( $n=1$ refit) (Fig. 9 and 11), even if the synchronicity cannot be demonstrated. This feature is also observed at other Palaeolithic sites (i.e. Vaquero et al. 2012a; Bargalló et al. 2016; 2020). Carcasses were exploited in the same areas and only humans and artefacts moved between the different subsistence activities areas.

To sum up, level 4.1 of the Abri du Maras represents recurrent short-term occupations, and not a mass hunting of reindeers during one main occupation, marked by faint living floors and distinctive anthropogenic facies. Neanderthals brought materials from a collecting perimeter of $30 \mathrm{~km}$ and introduced some already knapped artefacts, especially during autumn for hunting reindeers and/or processing carcasses of reindeers. Some types of flint show that Neanderthal had to cross the Ardèche River to reach the shelter. Carcass processing indicates a low level of fracturing implying the recovery of meat and consumption on the spot of some marrow. Micro-wear traces and residues support that both butchering and domestic activities were performed at the site. Four pieces that refit show traces related with cutting plants and whittling wood (Hardy et al. 2013). There are not clear areas of specialized activities but there is intentional movement of some artefacts. At this juncture, it is not possible to estimate the size of the group in question but it may have been a few individuals or a family group. The absence of carnivore tooth marks on the bones abandoned on the site could be possibly explained by rapid burial, or repeated human visits to the site despite the indications of primarily autumnal occupations. 
ephemeral occupations for Neanderthals. (Gabucio et al. 2018; Marín et al. 2019). At the nearby site of Payre, during MIS 7, we observed short-term occupations with a diversity of flint, mainly local (less than 30 $\mathrm{km}$ ), the differences being in the ratio of alluvial or colluvial flint collected (Moncel et al. 2018). Most of the types of flints Payre were similar to those of the Abri du Maras indicating that, over time, Neanderthals in the region used a similar land use strategy for flint collecting (for instance, for good quality Barremian Bedoulian flint - F14 and F34). For MIS 4-3, the Abri des Pêcheurs, located to the west in the Chassezac Valley, and the Barasses II cave (Balazuc) along the Ardèche River, the records suggest brief and recurrent occupations (bivouacs) (Moncel et al. 2008, 2018, 2019; Daujeard et al., 2019b). These sites only contain flakes and a few cores in flint with limited use of local quartz or basalt pebbles. They also have a wider diversity of flint types from alluvial deposits and colluviums from a large perimeter extending in several directions, from 10 to $30 \mathrm{~km}$. This suggests that toolkits may have circulated from site to site.

Our combined results provide new data on late Neanderthal short-term occupations regarding level 4.1 of the Abri du Maras. The use of toolkits (points, flakes, blades and some cores brought to the site), specialized seasonal hunting of reindeer, carcass processing in situ and repeat disposal of lightning-related materials at the same place indicate specialized, short occupations of the site by Neanderthal groups. The lack of a formal hearth may not mean lack of fire in general (contra Dibble et al. 2018) but in contrast a longmaintained knowledge of suitable fuel issued from lightning-struck wood. Indeed, distinct activity areas which vary in time and space suggest repeated occupation by one or several groups, probably centered on this specialized and seasonal reindeer hunt. Moreover, this evidence could represent shared common traditions regarding lithic, hunting and butchery practices. Comparison with Neanderthal MIS 3 sites in Europe, such as Abric Romaní, Teixoneres, El Salt, El Pastor or La Quebrada, indicates a high diversity of modes of occupation and solutions for exploitation of the local territory. The picture that emerges from Abri du Maras and other MIS 3 sites in Europe shows that late Neanderthals found multiple solutions to the exploitation of local conditions across southern Europe (Delagnes and Rendu 2011; Di Modica 2011; Sánchez-Hernández et al. 2014; Vidal-Matutano et al. 2015; Villaverde et al. 2017; Mallol et al. 2019; Mayor et al. 2020; Picin et al. 2020), emphasizing their behavioural adaptability.

\section{Acknowledgements}

We thank the editors of this special issue of the Topical Collection on Settlement Patterns Dynamics of the Middle Paleolithic and Middle Stone Age to include this manuscript.

We would like to thank Dr Vincenzo Spagnolo and the two anonymous reviewers for their useful comments that improved the papers.

\section{Funding information}

The excavations at the Abri du Maras are supported by the French Ministry of Culture, Service Régional de l'Archéologie Rhône-Alpes-Auvergne under the supervision of M-H. Moncel. MG Chacón, F. Rivals and $E$. Allue research is funded by the CERCA Programme/Generalitat de Catalunya, the Spanish Ministry of Science, Innovation and Universities (MICINN) projects HAR2016-76760-C3-1-P and PID2019-103987GB-C31 and the Catalan Government Research Group 2017 SGR 836.

\section{Compliance with ethical standards \\ Conflict of interests: The authors declare that they have no conflict of interests.}

\section{Authors Contributions}

M.-H.M., M.G.CH., D.V. and M-A.C. designed and conceptualized the paper, wrote the initial draft and prepared the figures, tables and supplementary information. Spatial analyses were made by M.G.CH. and 
D.V., for the lithic and faunal remains respectively. D.V. performed the faunal refits and M.G.CH. and A.E. the lithic ones. Zooarchaeology and taphonomy analysis of large mammals was carried out by C.D and D.V. Ungulate dental micro-wear was done by F.R. Fish remains were studied by P.B. Microstratigraphic analysis was made by M.-A.C. Geology was done by S.P. Lithics were studied by M.-H.M., M.G.CH. and A.E. B.H. did the micro-wear and residues analysis on lithics. Petrographic analysis of flint was done by P.F. E.A. made the charcoal analysis. R.G. performed the databases. Excavations were conducted by M.-H.M. All the authors have interpreted and discussed the data obtained and commented on the manuscript.

\section{References}

Adler DS, Conard NJ (2005) Tracking Hominins during the Last Interglacial complex in the Rhineland. In: Gamble C, Porr M (eds) The Hominid Indivual in context. Archaeological Investigations of Lower and Middle Palaeolithic Landscapes, Locales and Artefacts. Routledge. London and New York, pp 133-153

Allué E, Solé A, Burguet-Coca A (2017). Fuel exploitation among Neanderthals based on the anthracological record from Abric Romaní (Capellades, NE Spain). Quat. Int., 431:6-15

Bargalló A, Gabucio MJ, Rivals F (2016). Puzzling out a palimpsest: testing an interdisciplinary study in level O of Abric Romaní. Quat Inter 417: 51-65.

Bargalló A, Gabucio MJ, Gómez de Soler B, et al (2020) A Snapshot of a Short Occupation in the Abric Romaní Rock Shelter: Archaeo-Level Oa. In: Cascalheira J, Picin A (eds) In Short-Term Occupations in Paleolithic Archaeology. Springer International Publishing, Cham, pp 217-235

Bailey G (2007) Time perspectives, palimpsests and the archaeology of time. J Anthropol Archaeol 26:198223

Binford LR (1978) Dimensional analysis of behavior and site structure: learning from an Eskimo hunting stand. Am Antiq 43(3):330-361

Binford LR (1996) Hearth and home: the spatial analysis of ethnographically documented rock shelter occupations as a template for distinguishing between human and hominid use of sheltered space. In Proceedings of the XIII UISPP Congress, ABACO, Forli pp 229-239

Böeda E, Pelegrin J (1985) Approche expérimentale des amas de Marsagny. Archéologie Expérimentale 1:19-36

Britton K, V Grimes, L Niven, T Steele, S McPherron, M Soressi, TE Kelly, J Jaubert, JJ Hublin, MP Richards (2011) Strontium isotope evidence for migration in late Pleistocene Rangifer: Implications for Neanderthal hunting strategies at the Middle Palaeolithic site of Jonzac, France. J Hum Evol 61:176-185

Britton K, Gaudzinski-Windheuser S, Roebroeks W, Kindler L, Richards MP (2012) Stable isotope analysis of well-preserved 120,000-year-old herbivore bone collagen from the Middle Palaeolithic site of NeumarkNord 2, Germany reveals niche separation between bovids and equids. Palaeogeogr Palaeoclimatol Palaeoecol 333-334:168-177

Cascalheira J, Picin A (2020) Short-Term Occupations in Paleolithic Archaeology: Definition and Interpretation. Interdisciplinary Contributions to Archaeology. Springer edition. USA

Castel JC, Discamps E, Soulier MC, et al (2017) Neanderthal subsistence strategies during the Quina Mousterian at Roc de Marsal (France). Quat Int 433:140-156 
Chacón MG, Bargalló A, Gabucio MJ, Rivals F, Vaquero M (2015) Neanderthal Behaviors from a SpatioTemporal Perspective: An Interdisciplinary Approach to Interpret Archaeological Assemblages. In: Conard NJ, Delagnes A (eds) Settlement Dynamics of the Middle Paleolithic and Middle Stone Age, Vol. IV Kerns Verlag, Tübingen, pp 253-294

Combier J (1967) Le Paléolithique de l'Ardèche dans son cadre bioclimatique. Delmas, Bordeaux

Costamagno S, Meignen L, Beauval C, Vandermeersch B, Maureille B (2006) Les Pradelles (Marillac-le-Franc, France): A mousterian reindeer hunting camp? J Anthropol Archaeol 25:466-484

Courty MA (2001) Microfacies analysis assisting archaeological stratigraphy. In: Goldberg P, Holliday VT, Ferring CR (eds) Earth Sciences and Archaeology. Plenum-Kluwer, New York, pp 205-239

Courty MA (2012) Transformation pédologique des produits de combustion : approche expérimentale. Étude et Gestion des Sols, 19(1) : 41-45.

Courty MA (2017) Fuel origin and firing product preservation in archaeological occupation contexts. Quat Int 431:116-130

Courty MA, Goldberg P, Macphail R. (1989). Soils and micromorphology in archaeology. Cambridge:

Cambridge.

Courty MA, Carbonell E, Poch JV, Banerjee R (2012). Microstratigraphic and multi-analytical evidence for advanced Neanderthal pyrotechnology at Abric Romani (Capellades, Spain). Quaternary International, 247: 294-312.

Courty MA, Allué E, Henry A (2020). Forming mechanisms of vitrified charcoals in archaeological firingassemblages. Journal of Archaeological Science: Reports, 30, 102215

Cziesla E (1990) On refitting of stone artifacts. In: Cziesla E, Eickhoff S, Arts N,Winter D (eds) The big puzzle. International symposium on refitting stone artefacts. Monrepos 1987, Studies in modern archaeology, vol 1. Holos, Bonn, pp 9-44

Daujeard C, Moncel MH (2010) On Neanderthal subsistence strategies and land use: a regional focus on the Rhône Valley area in southeastern France. J Anthropol Archaeol 29(3):368-391

Daujeard C, Fernandes P, Guadelli JL, Moncel MH, Santagata C, Raynal JP (2012) Neanderthal subsistence strategies in Southeastern France between the plains of the Rhône Valley and the mid-mountains of the Massif Central (MIS 7 to MIS 3). Quat Int 252:32-47

Daujeard C, Abrams G, Germonpré M, Le Pape JM, Wampach A, Di Modica K, Moncel MH (2016) Neanderthal and animal karstic occupations from southern Belgium and south-eastern France: Regional or common features? Quat Int 411:179-197

Daujeard C, Vettese D, Britton K, Béarez P, Boulbes N, Crégut-Bonnoure E, Desclaux E, Lateur N, Pike-Tay A, Rivals F, Allue E, Chacón MG, Courty MA, Gallotti R, Hardy B, Puaud S, Moncel MH (2019a) Neanderthal selective hunting of reindeer in the Upper Pleistocene of Western Europe: the example of Abri du Maras (Southeastern France, Level 4.1, MIS 3). Archaeol Anthropol Sci 11:985-1011

Daujeard C., Brugal J.-P., Moncel M.-H., Fernandes P., Delvigne V., Lafarge A., Le Pape J.-M., Raynal J.-P. (2019b) - Neanderthals and Caprines. Two Upper Pleistocene Caves of Southeastern France. In: Gourichon L, Daujeard C, Brugal JP (eds) Rencontres internationales d'Antibes 2018. Hommes et Caprinés. De la montagne à la steppe, de la chasse à l'élevage. COLANTIB XXXIX, pp 77-99 
Debard E (1988) Le Quaternaire du Bas-Vivarais d'après l'étude des remplissages d'avens, de grottes et d'abris sous roche. Dynamique sédimentaire, paléoclimatologie et chronologie. Doc Lab Géologie Lyon 103

Defleur A, Bez JF, Crégut-Bonnoure E, Desclaux E, Fontugne M, Jeannet M, Magnon F, Talon B, Thinon M, Combier J (1994) Industries, biostratigraphie, restes humains et datation du gisement moustérien de la Baume Néron (Soyons, Ardèche). CR Acad Sci Paris 318(II):1409-1414

Delagnes A, Rendu W (2011) Shifts in Neanderthal mobility, technology and subsistence strategies in western France. J Archaeol Sci 38:1771-1783

De la Torre I, Martínez-Moreno J, Mora R (2012) When Bones are Not Enough: Lithic Refits and Occupation Dynamics in the Middle Palaeolithic Level 10 of Roca dels Bous (Catalonia, Spain). Bones tools - tools bones interplay between objects Object 1349:13-23

Dibble, Harold L., Sandgathe, Dennis, Goldberg, Paul, et al (2018) Were Western European Neanderthals able to make fire? J Paleo Archaeol 1(1):54-79

Di Modica K (2011) Les productions lithiques du Paléolithique moyen de Belgique : variabilité des systèmes d'acquisition et des technologies en réponse à une mosaïque d'environnements contrastés. Dissertation, Muséum National d'histoire Naturelle, Paris

Discamps E, Royer A (2017) Reconstructing palaeoenvironmental conditions faced by Mousterian hunters during MIS 5 to 3 in southwestern France: A multi-scale approach using data from large and small mammal communities. Quatern Int 433:64-87

Discamps E, Faivre JP (2017) Substantial biases affecting Combe-Grenal faunal record cast doubts on previous models of Neanderthal subsistence and environmental context. J Archaeol Sci 36:128-132

Ekshtain R, Malinsky-Buller A, Greenbaum N, Mitki N, Stahlschmidt MC, Shahack-Gross R, et al. (2019) Persistent Neanderthal occupation of the open-air site of 'Ein Qashish, Israel. PLoS ONE 14(6):e0215668

Enloe JG (2010) Refitting bones: negative evidence, site structure and social organisation. Lithic Technol 35(1):63-71

Enloe J, David F (1989) Le remontage des os par individus : le partage du renne chez les Magdaléniens de Pincevent (La Grande Paroisse, Seine-et-Marne). Bull Soc Préhist Fr 86(9) :275-281

ESRI (2014) ArcGIS for Desktop. Environmental Systems Research Institute, Redlands, 10.2.2. http://www.esri.com

Fernández-Laso MC (2010) Remontajes de restos faunísticos y relaciones entres áreas domésticas en los niveles $K, L$ y $M$ del Abric Romaní (Capellades, Barcelona, España). Dissertation, Univeristat Rovira i Virgili, Tarragona

Fernández-Laso MC, Rosell J, Blasco R, Vaquero M (2020) Refitting bones: Spatial relationships between activity areas at the Abric Romaní Level M (Barcelona, Spain). J Archaeol Sci Reports 29:102188

Gabucio MJ, Cáceres I, Rivals F, Bargalló A, Rosell J, Saladié P, Vallverdú J, Vaquero M, Carbonell E. 2018. Unraveling a Neanderthal palimpsest from a zooarcheological and taphonomic perspective. Archaeo Anthropol Sci. 10:197-222

Gaudzinski-Windheuser S (2006) Monospecific or species-dominated faunal assemblages during the Middle Paleolithic in Europe. In: Hovers E, Kuhn SL (eds) Transitions before the Transition. Springer, New York, pp 
Gaudzinski S, Roebroeks W (2000) Adults only. Reindeer hunting at the Middle Palaeolithic site Salzgitter Lebenstedt, Northern Germany. J Hum Evol 38: 497-521.

Gaudzinski-Windheuser S, Niven L (2009) Hominin subsistence patterns during the Middle and Late Paleolithic in Northwestern Europe. In: Hublin JJ, Richards MP (eds) The Evolution of Hominid Diets: Integrating Approaches to the Study of Palaeolithic Subsistence. Springer, Dordrecht, pp 97-109.

Ge, T., Courty, M.A., Wattez, J. and Matthews, W. (1993). Sedimentary formation processes of occupation surfaces. In « Formation processes in archaeological context », P. Goldberg, M. Petraglia and D.T. Nash (eds.). Monographs in World Archaeology 17: 149-163. Madison, Wisconsin: Prehistory Press

Genty D, Combourieu-Nebout N, Peyron O, Blamart D, Wainer K, Mansuri F, Ghaleb B, Isabello L, Dormoy I, von Grafenstein U, Bonelli S, Landais A, Brauer A (2010) Isotopic characterization of rapid climatic events during OIS3 and OIS4 in Villars Cave stalagmites (SW-France) and correlation with Atlantic and Mediterranean pollen records. Quat Sci Rev 29:2799-2820

Gilles R (1950) Présentation des silex taillés d'un abri-sous-roche du département de l'Ardèche. Bull Soc Préhist Fr 47:202

Goldberg, P., and Berna, F. (2010). Micromorphology and context. Quaternary International 214.1-2 : 56-62.

Hardy BL, Moncel MH, Daujeard C, Fernandes P, Béarez P, Desclaux E, Chacon Navarro MG, Puaud S, Gallotti R (2013) Impossible Neanderthals? Making string, throwing projectiles and catching small game during Marine Isotope Stage 4 (Abri du Maras, France). Quat Sci Rev 82:23-40.

Hardy B. L., Moncel M-H., Kerfant C., Lebon M., Bellot-Gurlet L., Mélard N. (2020) Direct evidence of Neanderthal fibre technology and its cognitive and behavioral implications. Nature. Scientific Report 10, 4889. https://doi.org/10.1038/s41598-020-61839-w

Henry DO (2012) the Palimpsest Problem, Hearth Pattern Analysis, and Middle Paleolithic Site Structure. Quatern Intern 247:246-266

Henry DO, Hall SA, Hietala HJ, Demidenko YE, Usik VI, Rosen AM, Thomas PA (1996) Middle Paleolithic behavioral organization: 1993 excavation of Tor Faraj, southern Jordan. J Field Archaeol 23:31-53

Henry DO, Hietala HJ, Rosen AM, Demidenko YE, Usik VI, Armagan TL (2004) Human behavioural organization in the Middle Paleolithic: were Neanderthals different? Amer Anthropol 106:17-31

Higham T, Douka K, Wood R, Bronk Ramsey C, Brock F, Basell L, Camps M, Arrizabalaga A, Baena J, BarrosoRuíz C, Bergman C, Boitard C, Boscato P, Caparrós M, Conard NJ, Draily C, Froment A, Galván B, Gambassini P, Garcia-Moreno A, Grimaldi S, Haesaerts P, Holt B, Iriarte-Chiapusso MJ, Jelinek A, Jordá Pardo JF, MaílloFernández JM, Marom A, Maroto J, Menéndez M, Metz L, Morin E, Moroni A, Negrino F, Panagopoulou E, Peresani M, Pirson S, de la Rasilla M, Riel-Salvatore J, Ronchitelli A, Santamaria D, Semal P, Slimak L, Soler J, Soler N, Villaluenga A, Pinhasi R, Jacobi R (2014) The timing and spatiotemporal patterning of Neanderthal disappearance. Nature 512:306-309.

Hovers E, Malinsky-Buller a, Goder-Goldberger M, Ekshtain R (2011) Capturin a moment: Identifying shortlived activity locations in Amud Cave, Israel. In: Le Tensorer JM, Jagher R, Otte M (eds) The Lower and Middle Plaeolithic in the Middle East and Neighbouring Regions. Basel Symposium (May 8-10 2008) ERAUL 126, pp 101-114

Julien M, Karlin C, Valentin B (1992) Déchets de silex, déchets de pierres chauffés. De l'intéret des 
1079

1080

1081

1082

1083

1084

1085

1086

1087

1088

1089

1090

1091

1092

1093

1094

1095

1096

1097

1098

1099

1100

1101

1102

1103

1104

1105

1106

1107

1108

1109

1110

1111

1112

1113

1114

1115

1116

1117

1118

1119

1120

1121

1122

1123

1124

1125

1126

1127

1128

1129

1130

1131

1132

remontages à Pincevent (France). In: Hofman JL, Enloe JG (eds.) Piecing Together the Past: Applications of Refitting Studies in Archaeology. BAR International Series, vol. 578, Oxford, pp 287-295

Kedar Y, Kedar G, Barkai R (2020) Setting fire in a Paleolithic Cave: The influence of cave dimensions on smoke dispersal. J Archaeol Sci Rep 29:102112

Kuhn SL (1992) On planning and curated technologies in the Middle Palaeolithic. J Anthropol Res 48:185214

Kuhn SL (1995) Mousterian Lithic Technology. An Ecological Perspective. Princeton. University Press, New Jersey

Lucas G (2005) The Archaeology of time. Routledge, London

Lucas G (2012) understanding the Archaeological record. Cambridge university Press

Lyman RL (2008) (Zoo) Archaeological Refitting: A Consideration of Methods and Analytical. J Anthropol Res $64(2): 229-248$

Macphail RI, Goldberg P. (2018) Applied soils and micromorphology in archaeology. Cambridge University Press.

Machado J, Hernández CM, Galván B (2011) Contribución teórico-metodológica al análisis histórico de palimpsestos arqueológicos a partir de la producción lítica. Un ejemplo de aplicación para el Paleolítico medio en el yacimiento de El Salt (Alcoy, Alicante). Recerques Museo d'Alcoi 20:33-46

Machado J, Hernández CM, Mallol C, Galván B (2013) Lithic production, site formation and Middle Palaeolithic palimpsest analysis: in search of human occupation episodes at Abric del Pastor Stratigraphic Unit IV (Alicante, Spain). J Archaeol Sci 40(5):2254-2273

Machado J, Mayor A, Hernández CM, Galván B (2019) Lithic refitting and the analysis of Middle Palaeolithic settlement dynamics: a hightemporal resolution example from El Pastor rock shelter (Eastern Iberia). Archaeol Anthropol Sci 11:4539-4554

Malinsky-Buller A, Hovers E, Marder O (2011) Making time: 'living floors', 'palimpsests' and site formation processes-a perspective from the open-air Lower Paleolithic site of Revadim Quarry, Israel. J Anthropol Archaeol 30(2):89-101

Mallol C, Hernández C, Mercier N, Falguères C, Carrancho Á, Cabanes D. et al (2019) Fire and brief human occupations in Iberia during MIS 4: Evidence from Abric del Pastor (Alcoy, Spain). Sci Rep 9(1):1-11

Marín J, Rodríguez-Hidalgo A, Vallverdú J, Gómez de Soler B, Rivals F, Rabuñal JR, Pineda A, Chacón MG, Carbonell E, Saladié P (2019) Neanderthal logistic mobility from a taphonomic perspective of Abric Romaní (Capellades, Spain). Quat Sci Rev 225:106033

Mayor A, Hernández, CM, Machado J, Mallol C, Galván B (2020) On identifying Palaeolithic single occupation episodes: archaeostratigraphic and technological approaches to the Neanderthal lithic record of stratigraphic unit Xa of El Salt (Alcoi, eastern Iberia) Archaeol Anthropol Sci 12:84.

Modolo M, Rosell Ardèvol J, Thun Hohenstein U (2015) L'impiego dei rimontaggi ossei in due realtà del Paleolitico Medio: Abric Romani e Riparo Tagliente. In: Thun Hohenstein U, Cangemi M, Fiore I, De Grossi Mazzorin J (eds) Atti del $7^{\circ}$ Convegno Nazionale di Archeozoologia. Ferrara, pp 13-20

Moncel MH, Gaillard C, Patou-Mathis M (1994) L'Abri du Maras (Ardèche) : une nouvelle campagne de fouilles dans un site paléolithique moyen. Bull Soc Préhist Fr 91(6):363-368 
Moncel MH, Michel V (2000) Première tentative de datation par U-Th du site paléolithique moyen de l'abri du Maras. Bull Soc Préhist Fr 93(3):371-375

Moncel MH, Brugal JP, Prucca A, Lhomme G (2008) Mixed occupation during the Middle Palaeolithic: case study of a small pit-cave-site of Les Pêcheurs (Ardèche, south-eastern France). J Anthropol Archaeol 27(3): 382-398

Moncel MH, Daujeard C, Cregut-Bonnoure E, Boulbes N, Puaud S, Debard E, Bailon S, Desclaux E, Escude E, Roger T, Dubar M (2010) Nouvelles données sur les occupations humaines du début du Pléistocène supérieur de la moyenne vallée du Rhône (France). Les sites de l'Abri des Pêcheurs, de la Baume Flandin, de l'Abri du Maras et de la Grotte du Figuier (Ardèche). Quatern 21(4):389-415

Moncel MH, Daujeard C (2012) The variability of the Middle Palaeolithic on the right bank of the Middle Rhône Valley (southeast France): Technical traditions or functional choices? Quatern Int 247:103-124

Moncel MH, Chacón MG, La Porta A, Fernandes P, Hardy B, Gallotti R (2014) Fragmented reduction processes: Middle Palaeolithic technical behaviour in the Abri du Maras shelter, southeastern France. Quatern Int 350:180-204

Moncel MH, Allué E, Bailon S, Barshay-Szmidt C, Béarez P, Crégut-Bonnoure E, Daujeard C, Desclaux E, Debard E, Lartigot-Campin AS, Puaud S, Roger T (2015) Evaluating the integrity of palaeoenvironmental and archaeological records in MIS 5 to 3 karst sequences from southeastern France. Quatern Int 378:22-39

Moncel MH, Raynal JP, Fernandes P, Delvigne V, Hardy B (2018) Les différentes phases d'occupation de la cavité : fonction(s) du site. Le matériel lithique. In : Daujeard C (dir.) La Grotte des Barasses II (Balazuc) : entre Néandertaliens, bouquetins et carnivores. Des occupations du Pleistocène supérieur en moyenne vallée de l'Ardèche DARA 46, pp 109-128

Moncel MH, Fernandes P, Willmes M, James H, Grün R (2019) Rocks, Teeth, and Tools: New insights into early Neanderthal subsistence strategies in South-Eastern France from lithic reconstructions and strontium isotope analysis, PLoS ONE 14(4): e0214925

Mora R, Roy M, Martínez-Moreno J, Benito-Calvo A, Samper S (2020) Inside the Palimpsest: Identifying Short Occupations in the 497D Level of Cova Gran (Iberia). In: Cascalheira J, Picin A (eds) Short-Term Occupations in Paleolithic Archaeology, Interdisciplinary Contributions to Archaeology. Springer International Publishing, Cham, pp 39-69

Morin E, Tsanova T, Sirakov N, Rendu W, Mallye JB, Lévêque F (2005) Bone refits in stratified deposits: Testing the chronological grain at Saint-Césaire. J Archaeol Sci 32(7):1083-1098

Newcomer MH, Sieveking G d G (1980) Experimental flake scatter-patterns: a new interpretative technique. J Field Archaeol 7:345-352

Niven L, Steele TE, Rendu W, Mallye JB, McPherron SP, Soressi M, Jaubert J, Hublin JJ (2012) Neanderthal mobility and large-game hunting: The exploitation of reindeer during the Quina Mousterian at Chez-Pinaud Jonzac (Charente-Maritime, France). J Hum Evol 63:624-635

Niven L (2013) A diachronic evaluation of Neanderthal cervid exploitation and site use at Pech de l'Azé IV, France. In: Clark JL, Speth JD (eds.) Zooarchaeology and Modern Human Origins: Human Hunting Behavior during the Later Pleistocene, Vertebrate Paleobiology and Paleoanthropology. Springer, Dordrecht, pp 151161.

Nomade, S., Genty, D., Sasco, R., Scao, V., Féruglio, V., Baffier, D., Guillou H, Bourdier C, Valladas H, Reigner 
1187 1188 1189 1190 1191 1192 1193 1194 1195 1196 1197 1198 1199 1200 1201 1202 1203 1204 1205 1206 1207 1208 1209 1210 1211 1212 1213 1214 1215 1216 1217 1218 1219 1220 1221 1222 1223 1224 1225 1226 1227 1228 1229 1230 1231 1232 1233 1234 1235 1236 1237 1238 1239 1240

E, Debard E, Pastre J-F, Geneste J-M (2016) A 36,000-year-old volcanic eruption depicted in the ChauvetPont d'Arc Cave (Ardèche, France)?. PloS one 11(1).

O'Connell JF (1987) Alyawara site structure and its archaeological implications. Am Antiq 52(1):74-108

Picin A, Chacón MG, Gómez de Soler B, Blasco R, Rivals F, Rosell J (2020) Neanderthals mobile toolkit in short-term occupations at Teixoneres Cave (Moia, Spain). J Archaeol Sci Rep 29: 102165

Poplin F (1976) Remarques théoriques et pratiques sur les unités utilisées dans les études d'ostéologie quantitative, particulièrement en archéologie préhistorique. Thèmes spécialisés, IXe Congrès UISPP, Nice, 124-140.

Puaud S, Nowak M, Pont S, Moncel MH (2015) Minéraux volcaniques et alpins à l'abri du Maras (Ardèche, France) : témoins de vents catabatiques dans la vallée du Rhône au Pléistocène supérieur. $C \mathrm{R}$ Palevol 14:331-341

Real C, Sanchis A, Eixea A, Villaverde V (2019) Neanderthal subsistence and short-term human occupation patterns during MIS 5. New data from Abrigo de la Quebrada (Valencia, Spain). J Archeol Sci Rep 28:102056

Rendu W, Costamagno S, Meignen L, Soulier MC (2012) Monospecific faunal spectra in Mousterian contexts: Implications for social behavior. Quatern Int 247:50-58

Richard $M$, Falguères $C$, Pons-Branchu $E$, Bahain JJ, Voinchet $P$, Lebon $M$, Valladas $H$, Dolo JM, Puaud $S$, Rué M, Daujeard C, Moncel MH, Raynal JP (2015) Contribution of ESR/U-series dating to the chronology of late Middle Palaeolithic sites in the middle Rhône valley, southeastern France. Quat Geochronol 30(B):529-534

Richards MP, Taylor G, Steele T, McPherron SP, Soressi M, Jaubert J, Orschiedt J, Mallye JB, Rendu W, Hublin JJ (2008) Isotopic dietary analysis of a Neanderthal and associated fauna from the site of Jonzac (CharenteMaritime), France. J Hum Evol 55(1):179-185

Roebroeks W (1988) From find scatters to Early hominid behaviour. A study of Middle Palaeolithic riverside settlements at Maastricht-Belvédère (The Netherlands). Analecta Praehistorica Leidensia 21, Leiden

Romagnoli F, Vaquero M (2016) Quantitative stone tools intra-site point and orientation patterns of a Middle Palaeolithic living floor: A GIS multi-scalar spatial and temporal approach. Quartär 63, 47-60

Romagnoli F, Vaquero M (2019) The challenges of applying refitting analysis in the Palaeolithic archaeology of the twenty-first century: an actualised overview and future perspectives. Archaeol Anthropol Sci 11:4387-4396

Rosell J, Blasco R, Fernández-Laso MC, Vaquero M, Carbonell E (2012) Connecting areas: Faunal refits as a diagnostic element to identify synchronicity in the Abric Romaní archaeological assemblages, Quatern Int 252:56-67

Rosell J, Modesto-Mata M, Fernández-Laso C, Modolo M, Blasco R (2019) Refitting bones to reconstruct the diversity in Middle Palaeolithic human occupations: the case of the Abric Romaní site (Capellades, Barcelona, Spain). Archaeol Anthropol Sci 1: 4601-4619.

Ruebens K, Wragg Sykes RM (2016) Spatio-temporal variation in late Middle Palaeolithic Neanderthal behaviour: British bout coupé handaxes as a case study. Quatern Int 411:305-326

Sánchez-Hernández C, Rivals F, Blasco R, Rosell J (2014) Short, but repeated Neanderthal visits to Teixoneres Cave (MIS 3, Barcelona, Spain): a combined analysis of tooth microwear patterns and seasonality. J Archaeol Science 49:317-325 
Sisk ML, Shea JJ (2008) Intrasite spatial variation of the Omo Kibish middle stone age assemblages: artifact refitting and distribution Patterns. J Hum Evol 55(3):486-500

Solé A, Allué E, Carbonell E (2013) Hearth-related wood remains from Abric Romaní layer M (Capellades, Spain). J. Anthrop. Res 69:535-559

Szmidt CC, Moncel M-H, Daujeard C (2010) New data on the late Mousterian in Mediterranean France: first radiocarbon (AMS) dates at Saint-Marcel Cave (Ardèche). C. R. Palevol 9(4): 185-199

Soulier MC (2013) Entre alimentaire et technique : l'exploitation animale aux débuts du Paléolithique supérieur. Stratégies de subsistance et chaînes opératoires de traitement du gibier à Isturitz, La Quina aval, Roc-de-Combe et Les Abeilles. Dissertation. Université de Toulouse 2 Le Mirail

Spagnolo V, Marciani G, Aureli D, Berna F, Boscato P, Ranaldo F, Ronchitelli A (2016) Between hearths and volcanic ash: the SU 13 palimpsest of the Oscurusciuto rock shelter (Ginosa - southern Italy): analytical and interpretative questions. Quatern Int 417:105-121.

Spagnolo V, Marciani G, Aureli D, Berna F, Toniello, G, Astudillo F, Boschin F, Boscato P, Ronchitelli A (2019) Neanderthal activity and resting areas from stratigraphic unit 13 at the Middle Palaeolithic site of Oscurusciuto (Ginosa - Taranto, Southern Italy). Quat Sci Rev 217:169-193.

Spagnolo V, Marciani G, Aureli D, et al (2020a) Climbing the time to see Neanderthal behaviour's continuity and discontinuity: SU 11 of the Oscurusciuto Rockshelter (Ginosa, Southern Italy). Archaeol Anthropol Sci 12:54.

Spagnolo V, Aureli D, Martini I, Ekberg I, Boschin F, Crezzini J, Poggi G, Boscato P, Ronchitelli A (2020b) Short and close in time: overlapped occupation from the layer 56 of the Molare Rock shelter (Southern Italy). Archaeol Anthropol Sci 12: 1-35.

Stevenson MG (1991) Beyond the formation of hearth-associated artifact assemblages. In: Kroll EM, Price TD (eds.) The Interpretation of Archaeological Spatial Patterning. New York and London, Plenum Press, pp 269-299

Turq A, Roebroeks W, Bourguignon L, Faivre JP (2013) The fragmented character of Middle Palaeolithic stone tool technology. J Hum Evol 65(5):641-655

Uzquiano P, Yravedra J, Zapata BR, Garcia MJG, Sesé C, Baena J (2012) Human behaviour and adaptations to MIS 3 environmental trends (> 53-30 ka BP) at Esquilleu cave (Cantabria, northern Spain). Quat. Int. 252:8289

Vallverdú J, Allué E, Bischoff JL, Cáceres I, Carbonell E, Cebrià A, García-Antón D, Huguet R, Ibáñez N, Martínez K, Pastó I, Rosell J, Saladié P, Vaquero M (2005) Short human occupations in the Middle Palaeolithic level $i$ of the Abric Romaní rock-shelter (Capellades, Barcelona, Spain). J Hum Evol 48(2):157174

Vandevelde S, Brochier JÉ, Petit C, Slimak L (2017) Establishment of occupation chronicles in Grotte Mandrin using sooted concretions: Rethinking the middle to upper paleolithic transition. J Hum Evol 112:70-78

Vaquero M (2008) The History Of Stones: Behavioural Inferences And Temporal Resolution Of An Archaeological Assemblage From The Middle Palaeolithic. J Archaeol Sci 35(12):3178-3185

Vaquero M, Pastó I (2001) The definition of spatial units in Middle Palaeolithic sites. The hearth-related assemblages. J Archaeol Sci 28:1209-1220 
Vaquero M, Chacón MG, García-Antón MD, Gómez de Soler B, Martínez K, Cuartero F (2012a) Time and space in the formation of lithic assemblages: the example of Abric Romaní level J Quat Int 247:162-181

Vaquero M, Chacón MG, Cuartero F, García-Antón MD, Gómez de Soler B, Martínez K (2012b) The lithic assemblage of level J. In: Carbonell E (ed) High Resolution Archaeology and Neanderthal Behavior: Time and Space In Level J of Abric Romaní (Capellades, Spain). Vertebr Paleobiol Paleoanthropol Book Series. Springer, Dordrecht, pp 189-311

Vaquero M, Bargalló A, Chacón MG, Romagnoli F, Sañudo, P (2015) Lithic recycling in a Middle Paleolithic expedient context: Evidence from the Abric Romaní (Capellades, Spain), Quatern Inter 361:212-228

Vaquero M, Romagnoli F, Bargalló A, Chacón MG, Gómez de Soler B, Picin A, Carbonell E (2019) Lithic refitting and intrasite artifact transport: a view from the Middle Paleolithic. Archaeol Anthropol Sci 11(9):4491-4513

Vettese D (2014) Le traitement des carcasses d'ongulés chez les Néanderthaliens de l'Abri du Maras (Ardèche, MIS4) / individualisme ou poids des traditions?. Master Dissertation. Muséum national d'Histoire naturelle, Paris

Vettese D, Daujeard C, Blasco R, Borel A, Caceres I, Moncel MH (2017) Neanderthal long bone breakage process: Standardized or random patterns? The example of Abri du Maras (Southeastern France, MIS 3). J Archaeol Sci Rep 13:151-163

Vidal-Matutano P (2017) Firewood and hearths: Middle Palaeolithic woody taxa distribution from El Salt, stratigraphic unit Xb (Eastern Iberia). Quatern Intern 457:74-84

Vidal-Matutano P, Hernández CM, Galván B, Mallol C (2015) Neanderthal firewood management: evidence from Stratigraphic Unit IV of Abric del Pastor (Eastern Iberia). Quat. Sci. Rev. 111:81-93

Villa P, Mahieu E (1991) Breakage patterns of human long bones. J Hum Evol 21(1):27-48

Villaverde V, Eixea A, Zilhão J, Sanchis A, Real C, Bergadà M (2017). Diachronic variation in the Middle Paleolithic settlement of Abrigo de la Quebrada (Chelva, Spain). Quat Int 435:164-179. 
Table 1 Categories of artefacts and raw materials of the level 4.1

\begin{tabular}{|c|c|c|c|c|c|c|c|c|c|c|c|}
\hline & Basalt & Limestone & $\begin{array}{l}\text { Siliceous } \\
\text { limestone }\end{array}$ & Granit & Sandstone & Quartz & Quartzite & Schist & Flint & Ind & Total \\
\hline Debris & & 1 & 1 & 1 & 1 & 36 & & & 137 & 3 & 180 \\
\hline Flakes & 6 & 2 & 3 & 3 & 1 & 45 & & 1 & 646 & 1 & 708 \\
\hline $\begin{array}{l}\text { Fragments } \\
\text { of flake }\end{array}$ & 1 & & 2 & 2 & & 8 & & & 327 & & 340 \\
\hline $\begin{array}{l}\text { Entire- } \\
\text { broken } \\
\text { pebbles }\end{array}$ & 5 & 1 & & 8 & 2 & 9 & 2 & 1 & 2 & 2 & 32 \\
\hline $\begin{array}{l}\text { Blades- } \\
\text { bladelets }\end{array}$ & 1 & & 2 & & & 2 & 1 & & 202 & & $\begin{array}{l}208 \\
10.2 \%\end{array}$ \\
\hline $\begin{array}{l}\text { Micro- } \\
\text { debris }\end{array}$ & & & & & & 3 & & & 164 & & 167 \\
\hline Cores & & & & & & & & & 51 & & $\begin{array}{l}51 \\
2.5 \%\end{array}$ \\
\hline $\begin{array}{l}\text { Pebble- } \\
\text { tools }\end{array}$ & & & & & & 1 & & & & & 1 \\
\hline $\begin{array}{l}\text { Small flakes } \\
(<15 \mathrm{~mm})\end{array}$ & & & 1 & & & 4 & & & 268 & & 273 \\
\hline Points & & 1 & 1 & & & & & & 79 & & $\begin{array}{l}81 \\
3.9 \%\end{array}$ \\
\hline Total & 13 & 5 & 10 & 14 & 4 & 108 & 3 & 2 & 1876 & 6 & 2041 \\
\hline
\end{tabular}

Table 2 Distribution of refitting groups according to the number of remains and the type of refit: mechanical refit (green bone fracture refit [Gbf Refit] and dry bone fracture refit [Dbf Refit]) and anatomical refit (Anat. Refit) values between brackets are \%), NSP (Number of Specimen)

\begin{tabular}{cccccc}
\hline $\begin{array}{c}\text { Nb of } \\
\text { remains }\end{array}$ & Anat. Refits & Gbf Refits & Dbf Refits & $\begin{array}{c}\text { Total } \\
\text { refits }\end{array}$ & $\begin{array}{c}\text { Total } \\
\text { NR }\end{array}$ \\
\hline 2 & $11(12.5)$ & $35(39.8)$ & $18(20.5)$ & 64 & $\mathbf{1 2 8}$ \\
3 & $4(4.5)$ & $7(8.0)$ & $2(2.3)$ & 13 & $\mathbf{3 9}$ \\
4 & $2(2.3)$ & $3(3.4)$ & $1(1.1)$ & 6 & $\mathbf{2 4}$ \\
5 & $1(1.1)$ & $1(1.1)$ & & 2 & $\mathbf{1 0}$ \\
6 & $1(1.1)$ & & & 1 & 6 \\
7 & $1(1.1)$ & & & 1 & $\mathbf{7}$ \\
8 & $1(1.1)$ & & & 1 & $\mathbf{8}$ \\
\hline Total & $\mathbf{2 1 ( 2 3 . 9 )}$ & $\mathbf{4 6 ( 5 2 . 3 )}$ & $\mathbf{2 1 ( 2 3 . 9 )}$ & $\mathbf{8 8}$ & $\mathbf{2 2 2}$ \\
\hline
\end{tabular}

1355

1356

1357 1358 1359

Table 3 Distances of the faunal refits connections lines (cm): average, Max. (Maximum), Min (Minimum), Sd (standard deviation)

\begin{tabular}{|c|c|c|c|c|c|}
\hline & & All refits & Gbf refits & Dbf refits & Anat. refits \\
\hline \multirow{6}{*}{ 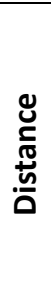 } & Max & 251.31 & 251.31 & 114.11 & 96.03 \\
\hline & Min & 0 & 0 & 0 & 0 \\
\hline & Average & 14.07 & 15.40 & 9.07 & 16.19 \\
\hline & $\mathrm{Sd}$ & 34.18 & 41.25 & 24.95 & 24.37 \\
\hline & Nb. Refit $=0$ & 46 & 28 & 13 & 5 \\
\hline & Nb total Refits & 88 & 46 & 21 & 21 \\
\hline
\end{tabular}


Table 4 Bone refits according the species. Nb refit (refit Number), NSP, values between brackets are \%

\begin{tabular}{|c|c|c|c|}
\hline & & Nb. refits & NR refits \\
\hline \multirow{5}{*}{ 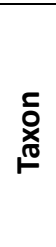 } & Rangifer tarandus & $61(69.3)$ & $152(68.5)$ \\
\hline & Equus ferus & $6(6.8)$ & $20(9)$ \\
\hline & Megaloceros giganteus & $3(3.4)$ & $9(4.1)$ \\
\hline & Und. & $18(20.5)$ & $41(18.5)$ \\
\hline & Total & $88(100)$ & $222(100)$ \\
\hline
\end{tabular}

Table 5 Bone refits according to anatomical part. Nb refits (Refit number), NR (Number of remains), Gbf refit (green bone fracture refit), Dbf refit (dry bone fracture refit), Anat. Refit (Anatomical refit); of total NR and total Nb refit. Values between brackets are $\%$

\begin{tabular}{lcccc}
\hline & Anat. Refits & Dry b.fract & Green b.fract & Total \\
\hline Ant. Autopode & $7(3.2)$ & $4(1.8)$ & $4(1.8)$ & $\mathbf{1 5 ( 6 . 8 )}$ \\
Axial & $2(.9)$ & & & $\mathbf{2}(.9)$ \\
Forlimb & $2(.9)$ & $5(2.3)$ & $43(19.4)$ & $\mathbf{5 0 ( 2 2 . 5 )}$ \\
Head & $26(11.7)$ & $2(.9)$ & & $\mathbf{2 8 ( 1 2 . 6 )}$ \\
Hindlimb & $6(2.7)$ & $6(2.7)$ & $17(7.7)$ & $\mathbf{2 9}(\mathbf{1 3 . 1})$ \\
Phal. Und. & $6(2.7)$ & & & $\mathbf{6 ( 2 . 7 )}$ \\
Post. Autopode & $19(8.6)$ & $13(5.9)$ & $28(12.6)$ & $\mathbf{6 0 ( 2 7 )}$ \\
Und & & $16(7.2)$ & $16(7.2)$ & $\mathbf{3 2 ( 1 4 . 4 )}$ \\
Total & $\mathbf{6 8 ( 3 0 . 6 )}$ & $\mathbf{4 6 ( 2 0 . 7 )}$ & $\mathbf{1 0 8 ( 4 8 . 6 )}$ & $\mathbf{2 2 2 ( 1 0 0 )}$ \\
\hline
\end{tabular}

Table 6 Total of pieces by type of stone and general type of RMU

\begin{tabular}{|c|c|c|c|c|c|c|c|}
\hline & & Basalt & Quartzite & Quartz & Limestone & Flint & Total \\
\hline \multirow{3}{*}{ 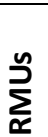 } & Isolated pieces & - & 3 & 6 & - & 11 & 20 \\
\hline & Groups & 2 & - & 7 & 1 & 22 & 32 \\
\hline & Total nb. pieces & 6 & 3 & 95 & 19 & 459 & 593 \\
\hline
\end{tabular}

Table 7 Detailed descriptions of each RMU identified in level 4.1 by stone type, total of pieces, technical categories, number of refits and technological consideration (see also Fig. 10 and 11)

\begin{tabular}{|c|c|c|c|c|c|}
\hline $\begin{array}{l}\text { Stone } \\
\text { type }\end{array}$ & $\begin{array}{l}\text { RMU } \\
\text { Number }\left(n^{\circ}\right)\end{array}$ & $\begin{array}{c}\text { Total } \\
n^{\circ} \\
\text { pieces }\end{array}$ & $\begin{array}{l}\text { Technical } \\
\text { categories }\end{array}$ & $\begin{array}{l}\text { No of } \\
\text { refits } \\
\text { by RMU }\end{array}$ & General description \\
\hline \multirow[t]{3}{*}{ Quartzite } & Isol-Qtzite 1 & 1 & $\begin{array}{l}1 \text { big } \\
\text { fragment of } \\
\text { pebble }\end{array}$ & - & $\begin{array}{l}\text { Rectangular quartzite pebble fractured intentionally in the } \\
\text { middle. Presents unifacial retouch on distal part. There are } \\
\text { percussion and macro-traces of use on the distal edge } \\
\text { (unknown material use). }\end{array}$ \\
\hline & Isol-Qtzite 2 & 1 & $\begin{array}{l}1 \text { broken } \\
\text { flake }\end{array}$ & - & $\begin{array}{l}\text { Broken Levallois quartzite flake (proximal zone conserved) } \\
\text { retouched in the proximal part with a simple notch. Fine } \\
\text { brownish grain good for knapping. Flake-tool introduced } \\
\text { into the site. }\end{array}$ \\
\hline & Isol_Qtzite 3 & 1 & 1 flake & - & $\begin{array}{l}\text { Levallois lengthen flake slightly déjèté knapped on a fine } \\
\text { grain quartzite. Use wear macro traces on lateral edge. }\end{array}$ \\
\hline Basalt & Bas-1 & 5 & $\begin{array}{l}1 \text { core } \\
2 \text { fragments } \\
3 \text { flakes }\end{array}$ & $\begin{array}{c}1 \\
(n=2)\end{array}$ & $\begin{array}{l}\text { Medium size pebble introduced in the site where is used to } \\
\text { obtain two or three flakes and then transform in a massive } \\
\text { tool with a thick edge (rabot). }\end{array}$ \\
\hline
\end{tabular}




\begin{tabular}{|c|c|c|c|c|c|}
\hline & Bas-2 & 1 & 1 fragment & & Fragment of hammerstone \\
\hline Limestone & Lim-1 & 19 & $\begin{array}{l}13 \text { flakes } \\
6 \text { fragments } \\
\text { of flakes }\end{array}$ & $\begin{array}{c}2 \\
(n=4)\end{array}$ & $\begin{array}{l}\text { Medium size flakes and fragments of flakes. The presence of } \\
\text { cortical products and flakes from reduction sequences (even } \\
\text { without cores) shows that the knapping strategies were } \\
\text { realized in the site following recurrent centripetal Levallois } \\
\text { strategies. This could be corroborated by the } 2 \text { identified } \\
\text { knapping refits }(4 \text { pieces), one of them with the longest } \\
\text { connection line }(371 \mathrm{~cm}) \text {. }\end{array}$ \\
\hline \multirow[t]{8}{*}{ Quartz } & Isol_Qtz (1 to 6) & 6 & $\begin{array}{l}3 \text { fragments of } \\
\text { flakes } \\
2 \text { flakes } \\
1 \text { flake-tool }\end{array}$ & - & $\begin{array}{l}\text { Isolated products of different varieties of quartz that cannot } \\
\text { be possible associate to the other RMU. All are products } \\
\text { coming from bifacial bipolar strategies (discoidal type) }\end{array}$ \\
\hline & Qtz-1 & 30 & $\begin{array}{l}1 \text { core } \\
1 \text { flake-tool } \\
7 \text { flakes } \\
19 \text { fragments } \\
\text { of flakes } \\
2 \text { fragmented } \\
\text { flakes }\end{array}$ & $\begin{array}{c}4 \\
(n=9)\end{array}$ & $\begin{array}{l}\text { The } 30 \text { pieces concerning all phases of the reduction } \\
\text { sequence (cortical flakes, débordant elements, small } \\
\text { fragments, tools, etc.). It seems that there are } 2 \text { different } \\
\text { pebbles that are introduced to be knapped in the site. The } \\
\text { tools of large formats are especially notches and } \\
\text { denticulates. The first flakes of cortical removal of the } \\
\text { nodule confirm the complete lithic sequences. Flakes are } \\
\text { normally dissymmetric and with thick formats (four refits). }\end{array}$ \\
\hline & Qtz-2 & 4 & $\begin{array}{l}3 \text { flakes } \\
1 \text { fragment } \\
\text { of flake }\end{array}$ & - & $\begin{array}{l}4 \text { isolated cortical pieces (more than } 90 \% \text { of the surface) } \\
\text { and } 1 \text { without that are shows macro-traces. Reduction } \\
\text { sequence very fragmented. Possible introduction of one big } \\
\text { cortical flake. }\end{array}$ \\
\hline & Qtz-3 & 2 & $\begin{array}{l}2 \text { fragments } \\
\text { of flakes }\end{array}$ & - & $\begin{array}{l}\text { Both are completely cortical. Flakes of hammerstone } \\
\text { produced by the impact? }\end{array}$ \\
\hline & Qtz-4 & 3 & $\begin{array}{l}3 \text { fragments } \\
\text { of flakes }\end{array}$ & - & $\begin{array}{l}\text { There are no more pieces of this RMU, only fragments of } \\
\text { flakes and some completely cortical. }\end{array}$ \\
\hline & Qtz-5 & 40 & $\begin{array}{l}2 \text { flake-tools } \\
10 \text { flakes } \\
17 \text { fragments } \\
\text { of flakes } \\
11 \text { fragmented } \\
\text { flakes }\end{array}$ & $\begin{array}{c}3 \\
(n=7)\end{array}$ & $\begin{array}{l}\text { Pebble introduced and knapped in the site, all the stages of } \\
\text { chaine opératoire were identified. The knapping products } \\
\text { show that some left, perhaps a part of them should be } \\
\text { transported after leaving the site as tool kit. realized. Some } \\
\text { big flakes were transformed by retouch in sidescraper and } \\
\text { denticulate. Presence of Siret fractures in various cases } \\
\text { (e.g.1 refit). }\end{array}$ \\
\hline & Qtz-6 & 5 & $\begin{array}{l}4 \text { fragments } \\
\text { of flake } \\
1 \text { fragmented } \\
\text { flake }\end{array}$ & - & $\begin{array}{l}2 \text { cortical flakes and some small fragments of flakes. Very } \\
\text { fragmented reduction sequence, introduction of } 1 \text { big } \\
\text { cortical flake. }\end{array}$ \\
\hline & Qtz-7 & 5 & $\begin{array}{l}1 \text { flake } \\
1 \text { flake-tool } \\
3 \text { fragments of } \\
\text { flakes }\end{array}$ & - & $\begin{array}{l}2 \text { isolated pieces, without cortex, retouched as a notch and } \\
\text { denticulate. Some fragments of broken flakes ( } 3 \text { ). } \\
\text { Fragmented reduction sequence and only presence of the } \\
\text { final stages. }\end{array}$ \\
\hline \multirow{8}{*}{ Flint } & Isol-FI (1 to 11$)$ & 11 & $\begin{array}{l}8 \text { flakes } \\
2 \text { fragments } \\
\text { of flake } \\
1 \text { flake-tool }\end{array}$ & - & $\begin{array}{l}\text { These isolated pieces belong all of them to bifacial } \\
\text { centripetal strategies, mainly Levallois but some of them } \\
\text { come from discoidal ones. We should point out two typical } \\
\text { Levallois points and one big Quina scraper. All these pieces } \\
\text { are pieces introduced already knapped to the site (tool kit) }\end{array}$ \\
\hline & Fl-1 & 2 & 2 flakes & - & $\begin{array}{l}2 \text { elongated Levallois flakes introduced into the site (tool } \\
\text { kit). }\end{array}$ \\
\hline & $\mathrm{Fl}-2$ & 12 & $\begin{array}{l}1 \text { core } \\
7 \text { flakes } \\
2 \text { fragmented } \\
\text { flakes } \\
1 \text { fragment of flake } \\
\end{array}$ & $\begin{array}{c}2 \\
(n=4)\end{array}$ & $\begin{array}{l}\text { Complete reduction sequence: cortical flakes (refit) peeling } \\
\text { the nodule and recurrent centripetal Levallois exploitation } \\
\text { (refit) obtaining large flakes. The core is abandoned } \\
\text { although it is not exhausted. }\end{array}$ \\
\hline & Fl-3 & 6 & $\begin{array}{l}\text { flakes } \\
1 \text { fragmented } \\
\text { flake }\end{array}$ & - & $\begin{array}{l}\text { Advanced fragmented reduction sequence with just few } \\
\text { flakes and small débitage (no refits). }\end{array}$ \\
\hline & Fl-4 & 3 & $\begin{array}{l}2 \text { flakes } \\
1 \text { fragment } \\
\text { of flake }\end{array}$ & - & $\begin{array}{l}\text { One elongated Levallois flake and two small broken flakes. } \\
\text { Fragmented reduction sequence that implies pieces } \\
\text { introduced already knapped. }\end{array}$ \\
\hline & Fl-5a & 17 & $\begin{array}{l}11 \text { flakes } \\
6 \text { fragments } \\
\text { of flakes } \\
1 \text { fragmented } \\
\text { flake } \\
\end{array}$ & - & $\begin{array}{l}\text { Advanced and fragmented reduction sequence with no } \\
\text { cortical elements. The knapping products are varied } \\
\text { (configuration, réaffûtage, etc.) and belongs to Levallois } \\
\text { strategies. }\end{array}$ \\
\hline & Fl-5b & 11 & 11 flakes & $\begin{array}{c}1 \\
(n=4)\end{array}$ & $\begin{array}{l}\text { Reduction sequence of flakes by recurrent centripetal } \\
\text { Levallois strategies. }\end{array}$ \\
\hline & $\mathrm{Fl}-6$ & 4 & 4 flakes & - & $\begin{array}{l}\text { Initial phase of the reduction sequence with the presence of } \\
4 \text { cortical flakes. There are no refits but RMU are located in }\end{array}$ \\
\hline
\end{tabular}




\begin{tabular}{|c|c|c|c|c|}
\hline \multirow{2}{*}{\begin{tabular}{|l|l|} 
& \\
\cline { 2 - 2 } & Fl-7
\end{tabular}} & & & & \multirow{2}{*}{$\begin{array}{l}\text { the same area of the site. } \\
\text { A set of } 1 \text { flake and } 4 \text { broken flakes (fragmented reduction } \\
\text { sequence). }\end{array}$} \\
\hline & 5 & $\begin{array}{l}1 \text { flake } \\
3 \text { fragments of } \\
\text { flake } \\
1 \text { fragmented } \\
\text { flake }\end{array}$ & - & \\
\hline Fl-8 & 2 & $\begin{array}{l}2 \text { fragmented } \\
\text { flakes }\end{array}$ & - & $\begin{array}{l}1 \text { isolated and a broken flake (no cortex). Pieces introduced } \\
\text { into the site already knapped (tool kit). }\end{array}$ \\
\hline FI-9 & 5 & $\begin{array}{l}3 \text { flakes } \\
2 \text { fragments } \\
\text { of flake }\end{array}$ & $\begin{array}{c}1 \\
(n=2)\end{array}$ & $\begin{array}{l}\text { Advanced reduction sequence. These knapping products } \\
\text { belong to centripetal recurrent Levallois strategies. }\end{array}$ \\
\hline Fl-10 & 9 & $\begin{array}{l}3 \text { fragments of } \\
\text { flake } \\
3 \text { fragmented } \\
\text { flakes } \\
3 \text { flakes } \\
\text { (1 point) }\end{array}$ & - & $\begin{array}{l}\text { Set of } 7 \text { Levallois flakes introduce to the site already } \\
\text { knapped. All come from Levallois strategies. }\end{array}$ \\
\hline Fl-11 & 6 & $\begin{array}{l}4 \text { flakes } \\
1 \text { fragment of } \\
\text { flake } \\
1 \text { fragmented } \\
\text { flake }\end{array}$ & - & $\begin{array}{l}\text { Isolated pieces related with an advance production phase. } \\
\text { All come from Levallois strategies. }\end{array}$ \\
\hline Fl-12 & 34 & $\begin{array}{l}1 \text { flake-tool } \\
14 \text { flakes } \\
7 \text { fragmented } \\
\text { flakes } \\
12 \text { fragments } \\
\text { of flakes }\end{array}$ & - & $\begin{array}{l}\text { Complete reduction sequence where all the technological } \\
\text { products are represented: cortical flakes, backed elements, } \\
\text { advanced flakes and tools, but no cores. Two possibilities } \\
\text { (1) the core was transported after the occupation, or (2) } \\
\text { some of the cores very patinated belongs to this RMU. }\end{array}$ \\
\hline Fl-13 & 231 & $\begin{array}{l}129 \text { flakes } \\
7 \text { flake-tools } \\
1 \text { core } \\
24 \text { fragmented } \\
\text { flakes } \\
70 \text { fragments } \\
\text { of flakes }\end{array}$ & $\begin{array}{c}6 \\
(n=13)\end{array}$ & $\begin{array}{l}\text { Complete reductions sequences. It is probably that exist } \\
\text { two or three pebbles which are knapped at the site. They } \\
\text { were differentiated by the type of cortex and some } \\
\text { macroscopic characteristics They come from the same } \\
\text { geological formation (same type of flint). }\end{array}$ \\
\hline Fl-14 & 4 & $\begin{array}{l}2 \text { flakes } \\
1 \text { fragment of } \\
\text { flake } \\
1 \text { fragmented } \\
\text { flake }\end{array}$ & - & $\begin{array}{l}3 \text { semi-cortical flakes (around } 25-50 \% \text { ), two with macro } \\
\text { traces of use. Reduction sequence is partial and } \\
\text { fragmented, no cores associated. }\end{array}$ \\
\hline Fl-15 & 4 & $\begin{array}{l}3 \text { fragments of } \\
\text { flake } \\
1 \text { flake-tool }\end{array}$ & $\begin{array}{c}1 \\
(n=2)\end{array}$ & Isolated pieces, some cortical. \\
\hline Fl-16a & 2 & $\begin{array}{l}1 \text { flake } \\
1 \text { fragmented } \\
\text { flake }\end{array}$ & - & Isolated cortical pieces. \\
\hline Fl-16b & 5 & $\begin{array}{l}1 \text { core } \\
1 \text { flake } \\
1 \text { fragment of } \\
\text { flake } \\
1 \text { fragmented } \\
\text { flake }\end{array}$ & - & $\begin{array}{l}\text { Isolated pieces of different phases of the reduction } \\
\text { sequence, so very fragmented. They belong to Levallois } \\
\text { strategies. }\end{array}$ \\
\hline Fl-16c & 3 & 3 flakes & - & $\begin{array}{l}\text { Isolated cortical pieces coming from the first phase of the } \\
\text { reduction sequence. }\end{array}$ \\
\hline FI-16d & 32 & $\begin{array}{l}2 \text { cores } \\
24 \text { flakes } \\
4 \text { fragments } \\
\text { of flake } \\
2 \text { fragmented } \\
\text { flakes }\end{array}$ & $\begin{array}{c}1 \\
(n=2)\end{array}$ & \multirow{3}{*}{$\begin{array}{l}\text { Complete reductions sequences knapped at the site. } \\
\text { All of them are related with different modalities of Levallois } \\
\text { strategies. } \\
\text { It is probably that in some cases exist two or three pebbles } \\
\text { which were differentiate by the type of cortex and some } \\
\text { macroscopic characteristics. They come from the same } \\
\text { geological formation (same type of flint). } \\
\text { Only one refit had been found, perhaps some pieces left } \\
\text { and where transported after leaving the site (fragmented } \\
\text { reduction sequence). }\end{array}$} \\
\hline FI-16e & 32 & $\begin{array}{l}3 \text { cores } \\
20 \text { flakes } \\
1 \text { fragmented } \\
\text { flake } \\
6 \text { fragments of } \\
\text { flakes }\end{array}$ & - & \\
\hline Fl-16f & 30 & $\begin{array}{l}3 \text { cores } \\
17 \text { flakes } \\
3 \text { fragmented } \\
\text { flakes } \\
9 \text { fragments of } \\
\text { flakes }\end{array}$ & - & \\
\hline
\end{tabular}


Table 8 Lithic refits by type of stone and number of pieces/refits from Level 4.1

\begin{tabular}{lccccc}
\hline & Flint & Limestone & Basalt & Quartz & Total \\
\hline Refits of 2 pieces & 10 & 2 & 1 & 5 & $\mathbf{1 8}$ \\
$\begin{array}{l}\text { Refits of 3 pieces } \\
\text { Refits of 4 pieces }\end{array}$ & 1 & - & - & 2 & $\mathbf{3}$ \\
\hline $\begin{array}{l}\text { Total Nb of } \\
\text { refitting }\end{array}$ & $\mathbf{1 2}$ & $\mathbf{2}$ & $\mathbf{1}$ & $\mathbf{7}$ & $\mathbf{2 2}$ \\
\hline
\end{tabular}

Table 9 Technological categories by type of stone of the refitted pieces of the Level 4.1

\begin{tabular}{|c|c|c|c|c|c|c|c|c|}
\hline & & \multicolumn{6}{|c|}{ Technological categories } & \multirow[b]{2}{*}{ Total } \\
\hline & & Cores & Flakes & $\begin{array}{c}\text { Fragments } \\
\text { of flake }\end{array}$ & $\begin{array}{l}\text { Broken } \\
\text { flakes }\end{array}$ & Flake-tools & Debris & \\
\hline \multirow{4}{*}{ 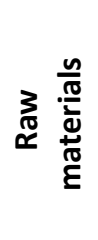 } & Basalt & & & & & & 2 & 2 \\
\hline & Quartz & 2 & 4 & 5 & 5 & & & 16 \\
\hline & Limestone & & 4 & & & & & 4 \\
\hline & Flint & 1 & 12 & 10 & 3 & 1 & & 27 \\
\hline & Total & 3 & 20 & 15 & 8 & 1 & 2 & 49 \\
\hline
\end{tabular}

\begin{tabular}{lccccc}
\hline & flint & limestone & basalt & quartz & Total \\
\hline $\begin{array}{l}\text { Knapping } \\
\begin{array}{l}\text { connection lines } \\
\text { Knapping fracture }\end{array}\end{array}$ & 8 & 2 & 1 & 4 & $\mathbf{1 5}$ \\
$\begin{array}{l}\text { connection lines } \\
\text { Conjoin (post-depositional }\end{array}$ & 1 & - & - & 5 & $\mathbf{6}$ \\
$\begin{array}{l}\text { Fractures) connection lines } \\
\text { Total }\end{array}$ & $\mathbf{1 5}$ & $\mathbf{2}$ & $\mathbf{1}$ & $\mathbf{9}$ & $\mathbf{2 7}$ \\
\hline
\end{tabular}

Table 11 Distances of the fauna refits connections lines (cm): average, Max. (Maximum), Min (Minimum), Sd (standard deviation)

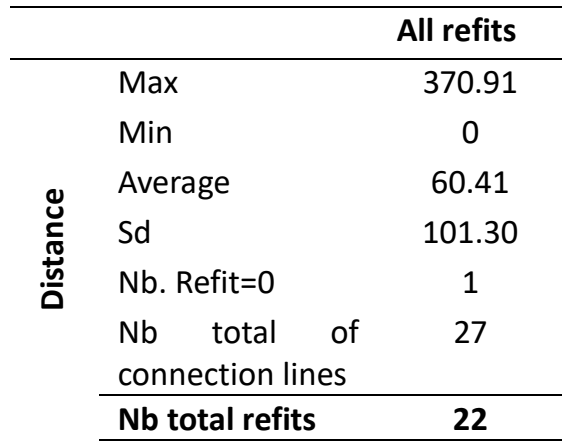



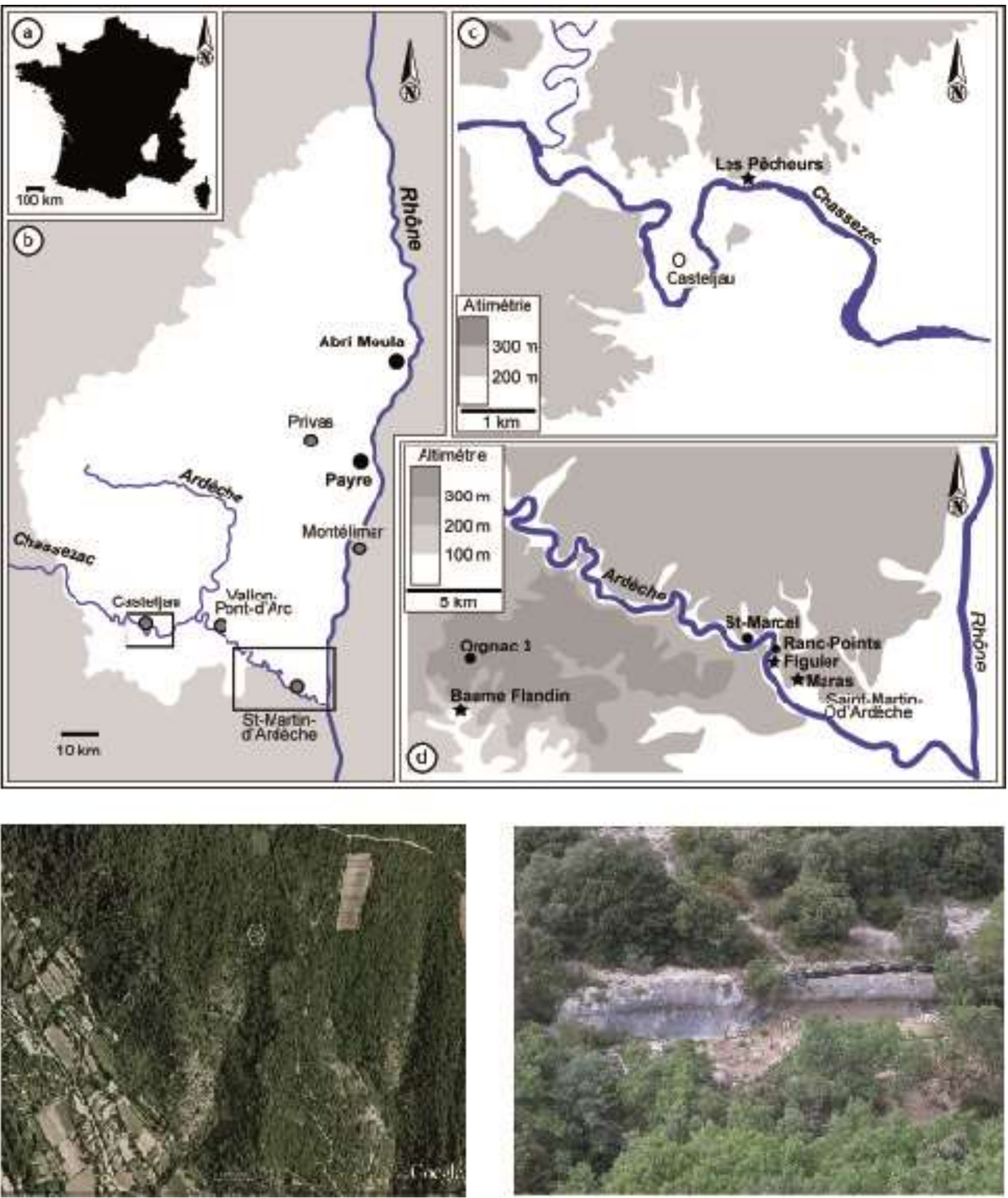

Fig. 1 Location of the Abri du Maras. Site situation on the edges of the Rhône valley and detailed view location near the Saint Martin d'Ardèche village 

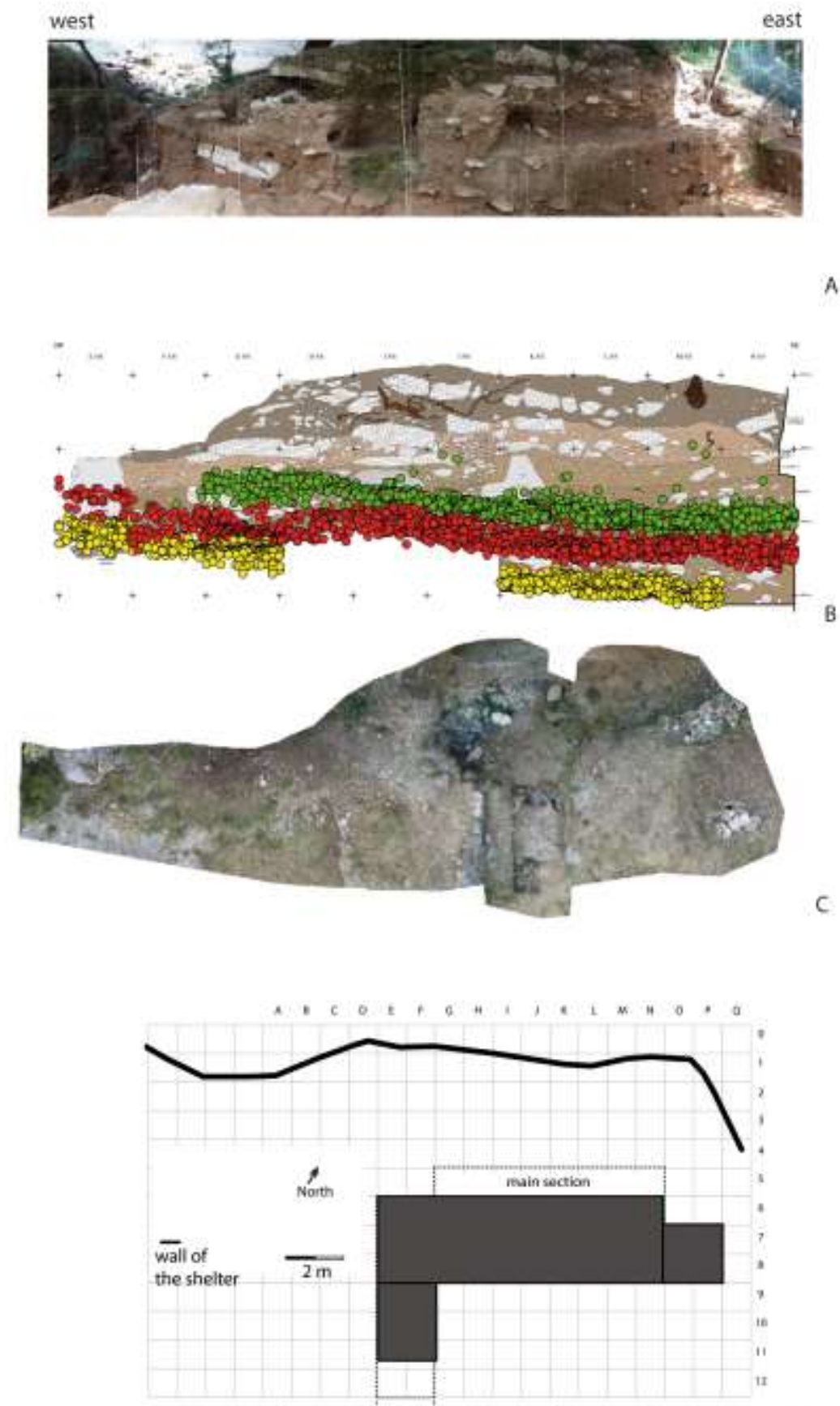

Fig. 2 A excavated area of level 4.1; B Vertical projection of the archaeological remains by levels (projection band 6 green level 4.1, red 4.2 and yellow); C Map of the excavated area for the level 4.1; D Vertical view of the site before the beginning of the excavation of 2009. The upper limit of the photo corresponds to the limit of the shelter wall (see the limit on map C). 


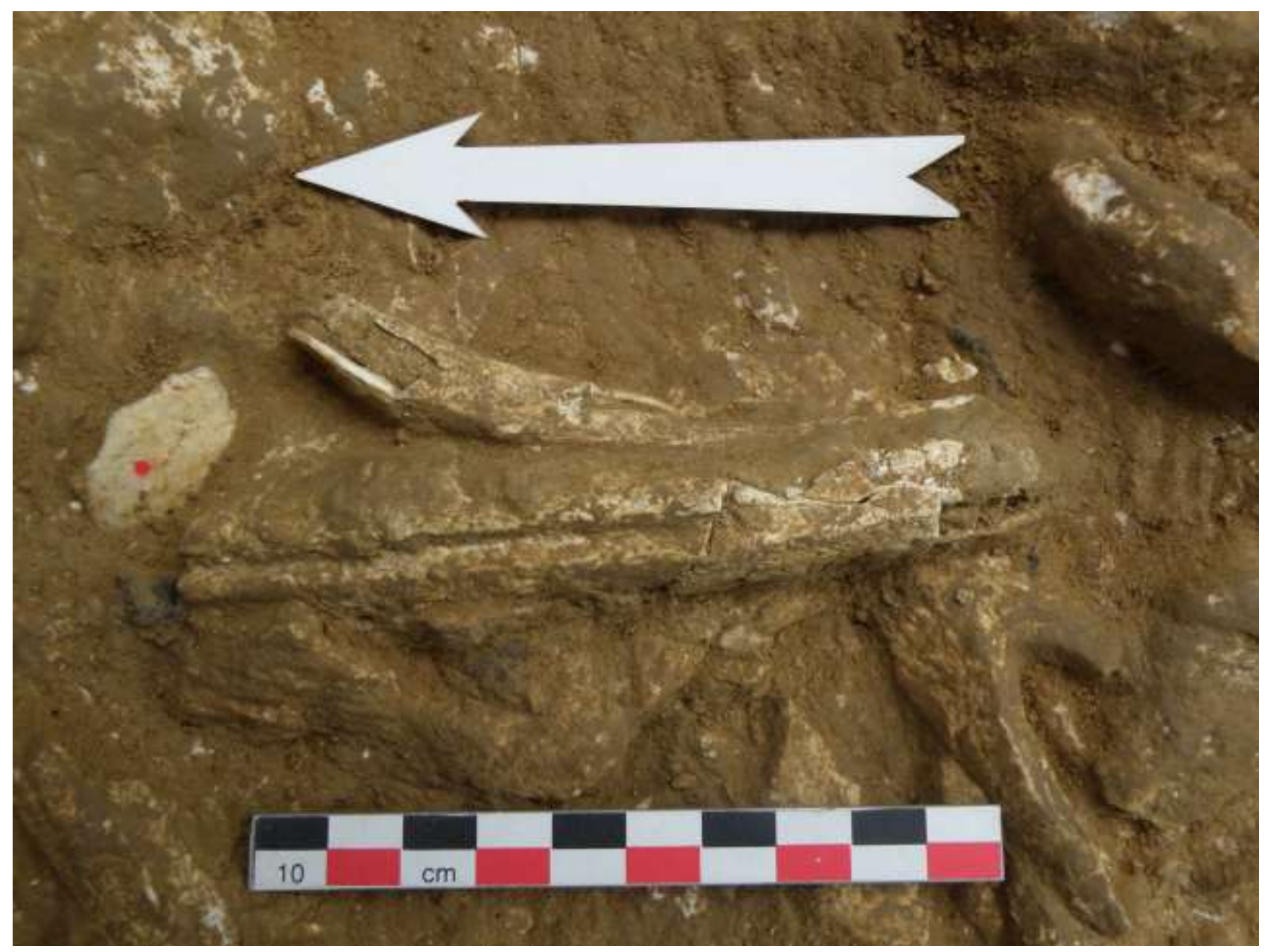

1420

1421

Fig. 3 Example of square J6, level 4.1 and density of bone remains and artefacts

\section{2}

1423

1424

1425

1426

1427

1428

1429

1430

1431

1432

1433

1434

1435

1436 

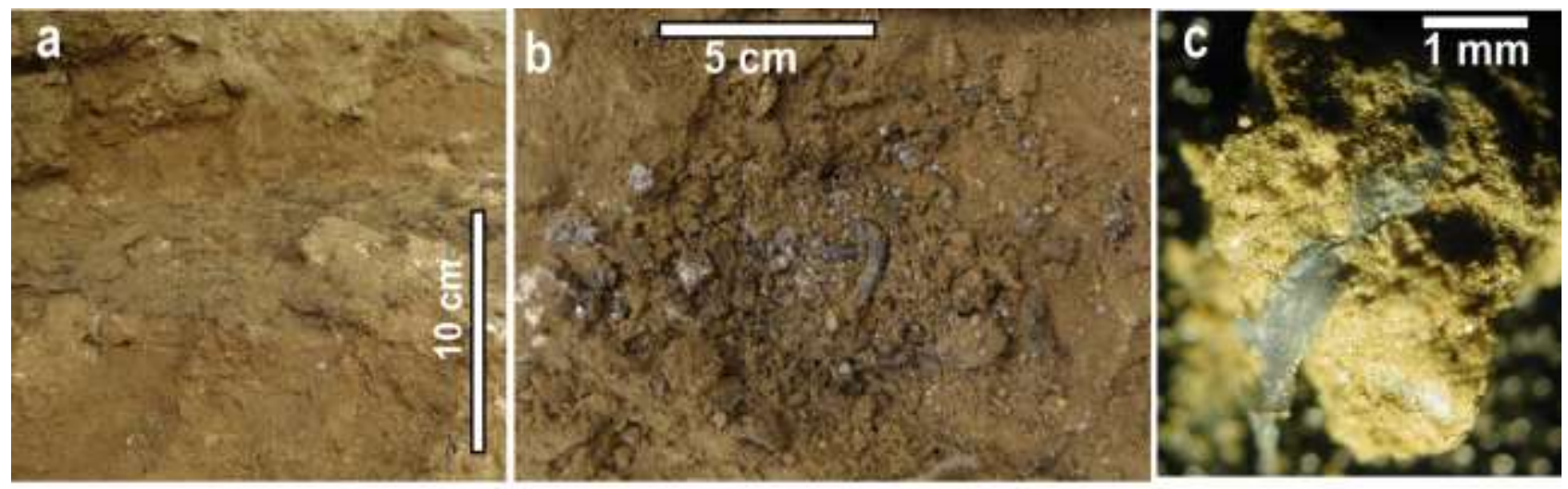

Fig. 1/MAC

1444 1445 1446 1447 1448
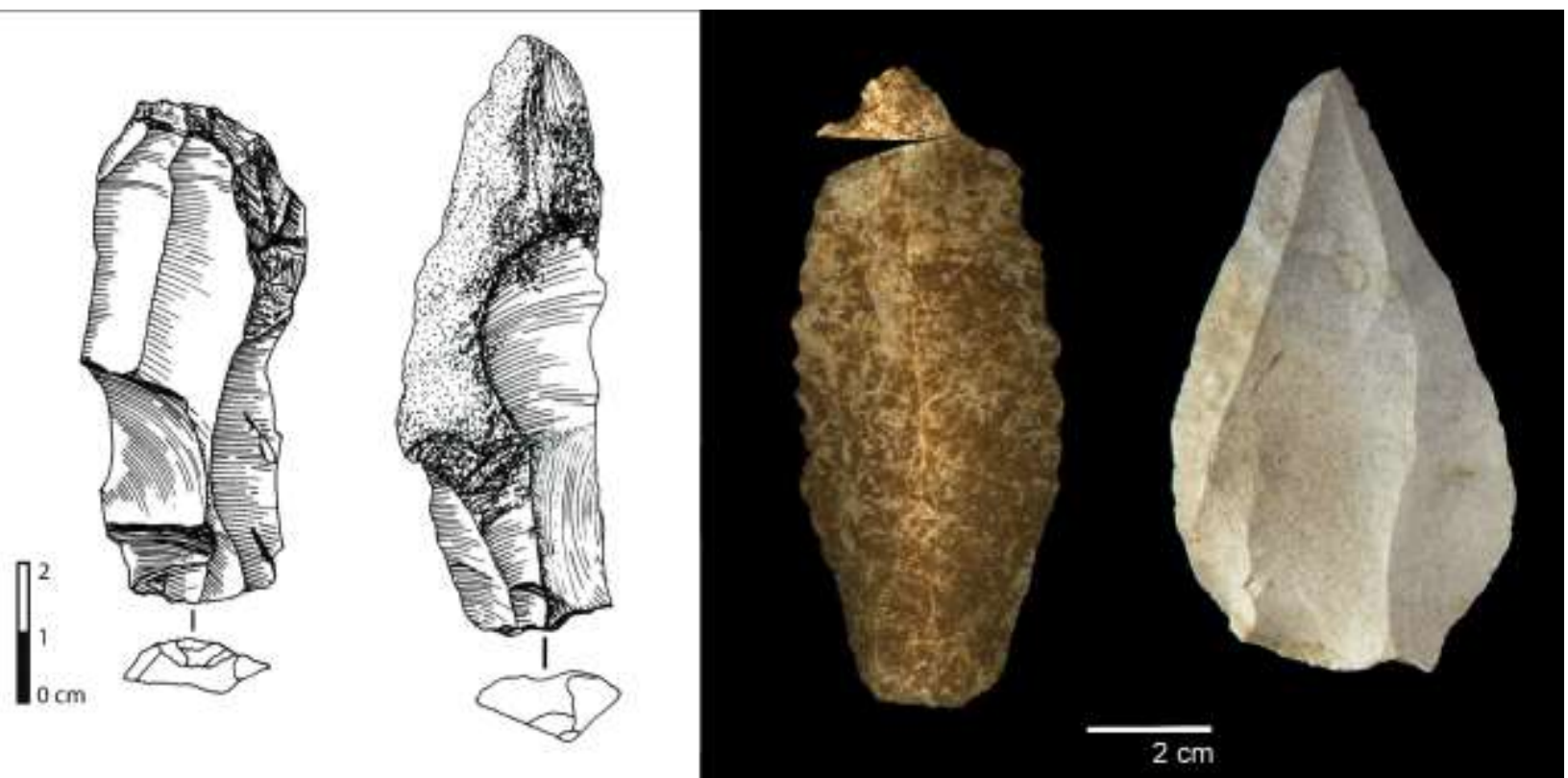

Fig. 4 Examples of elongated pieces and points brought to the site already worked (1) 


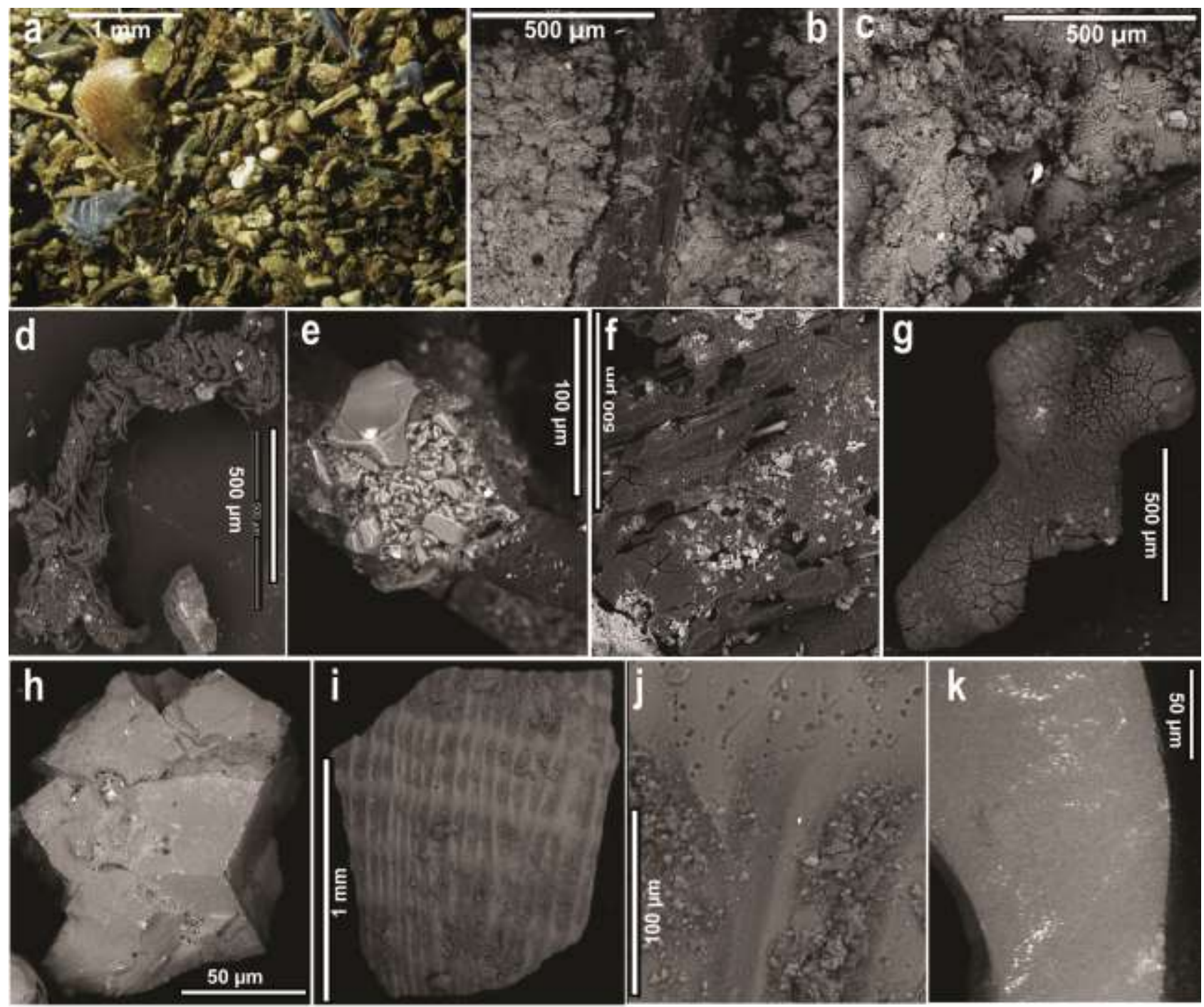

Fig. 2/MAC

1449 1450 1451 1452 1453 1454 1455 1456 1457 1458 1459 1460 1461 1462
Fig. 6 a Stereomicroscope view of the sand-sized fraction extracted by water-sieving of a greyish microaggregate lens in $15(258-262 \mathrm{~cm})$ : abundant white and coloured polymer films, filaments, aggregates, humified organic fragments, metal-splashed angular grains; b Back-scattered (BSE) SEM view of the greyish lens in 16 showing the imbrication of polymerized plant fibres (in black) with the silty clay microaggregates and the native metal inclusions (bright spots); c BSE-SEM view of the connected fish-scales and bones lying above the lens viewed in (b), also with abundant native metal inclusions (bright spots); $\mathbf{d}$ to $\mathbf{k}$ typical components of the microaggregate lenses in level 4.1; $\mathbf{d}$ nanostructured twisted polymer films with metal inclusions; e nanostructured composite filament showing lightning-formed quartz with $\mathrm{Fe}-\mathrm{Cr}-\mathrm{Ni}$ metal splash (in bright); f flash-pyrolyzed partly vitrified charcoal with metal inclusions (in bright); $\mathbf{g}$ flashpyrolyzed bone with metal inclusions (in bright); $\mathbf{h}$ exogenous angular quartz showing lightning-formed Fe$\mathrm{Cr}-\mathrm{Ni}$ metal splash on the angular edges; $\mathbf{i}$ flash-burnt shell fragment showing in $\mathbf{j}$ degassed vesicles and metal inclusions; $\mathbf{k}$ aligned droplets of $\mathrm{Fe}-\mathrm{Cr}-\mathrm{Ni}$ metal splash on a flint-flake. 


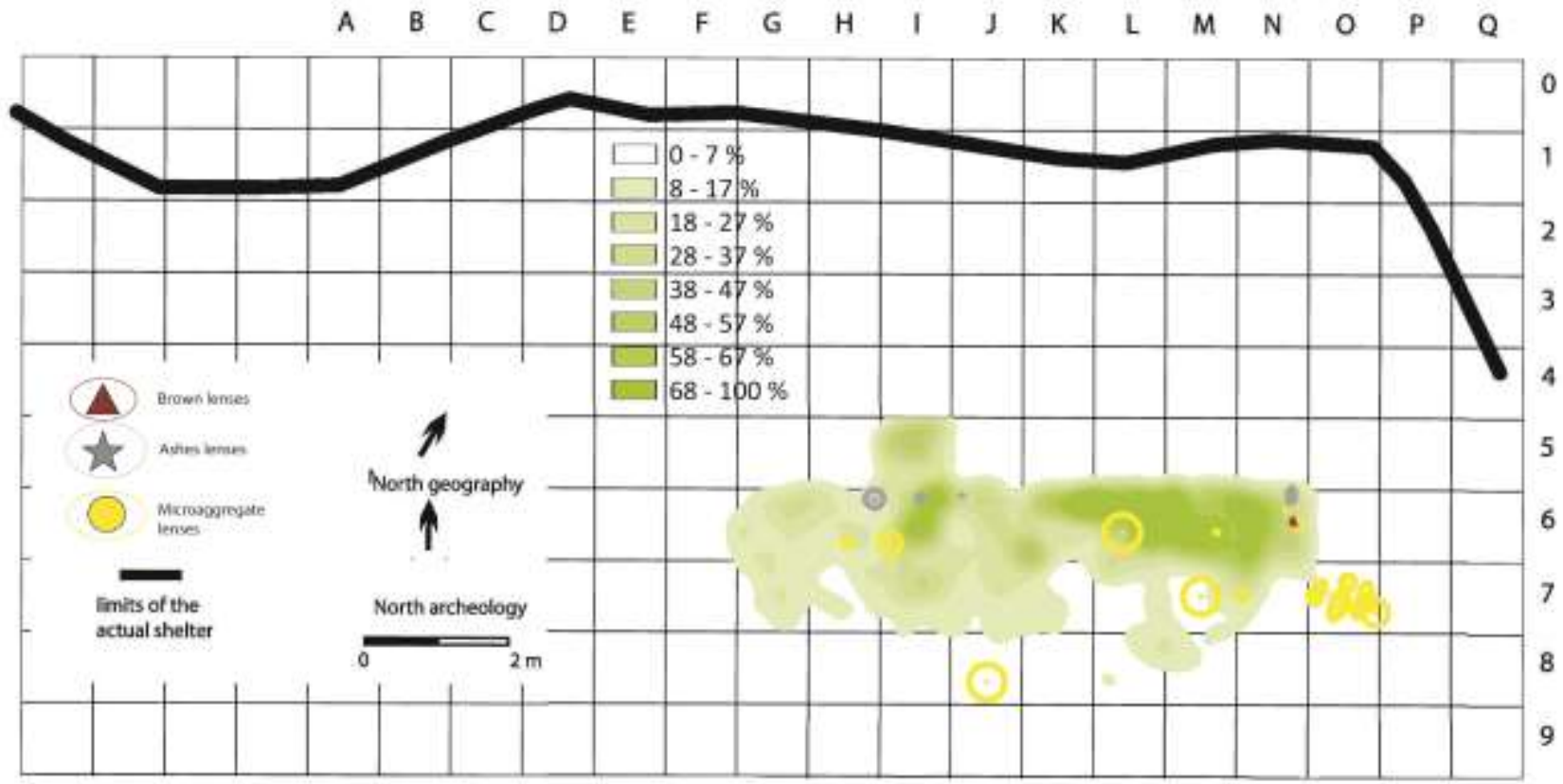

Fig. 7 Density maps and visual maps of all the archaeological remains Kernel density analysis) with the localisation of all type of microaggregate lenses from Maras level 4.1. 


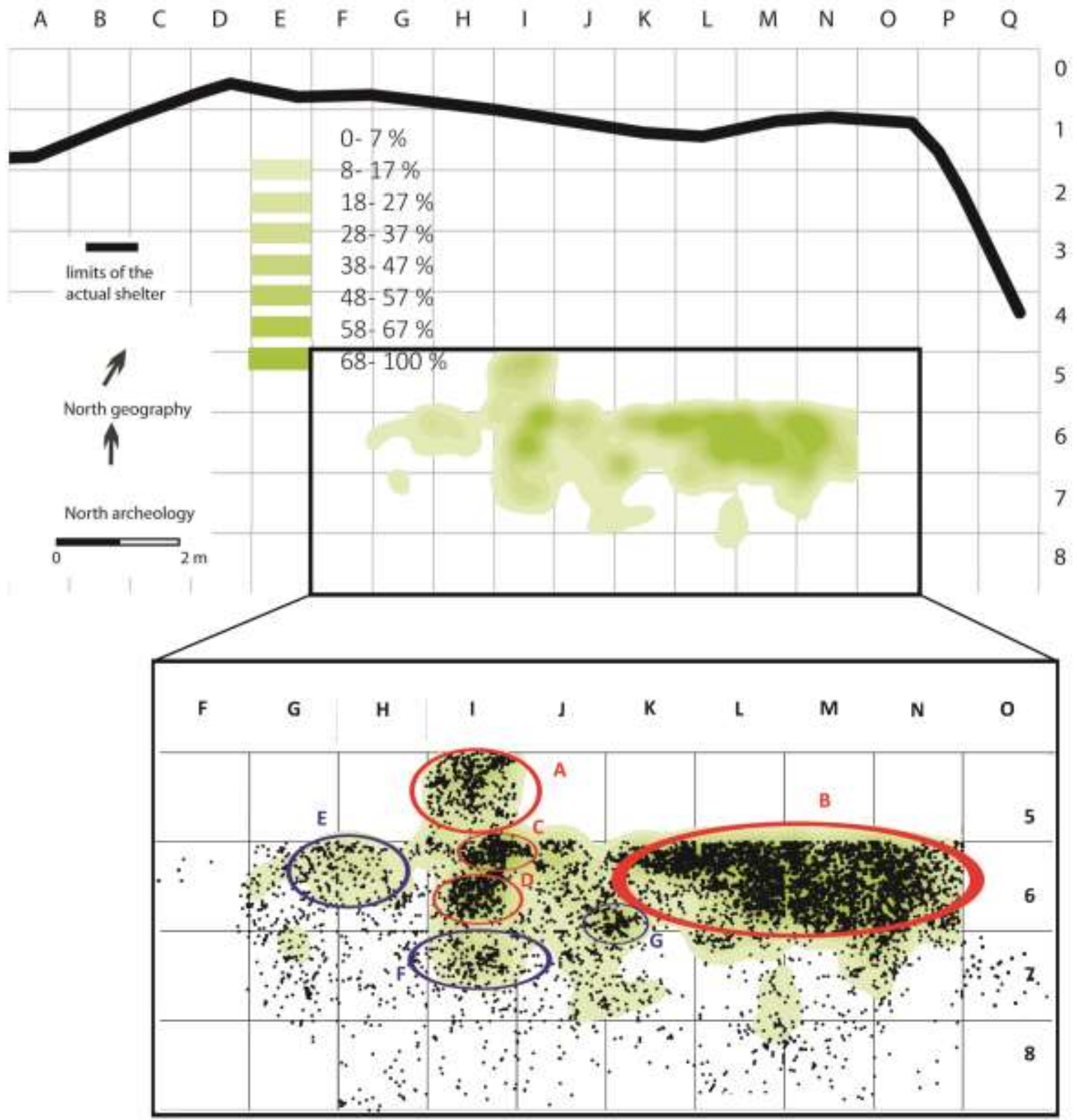

Fig. 8 Density maps and visual maps of all the remains from Maras level 4.1 (Kernel density analysis). Red circles show the accumulations areas with higher density of remains and the blue ones those with less remains 


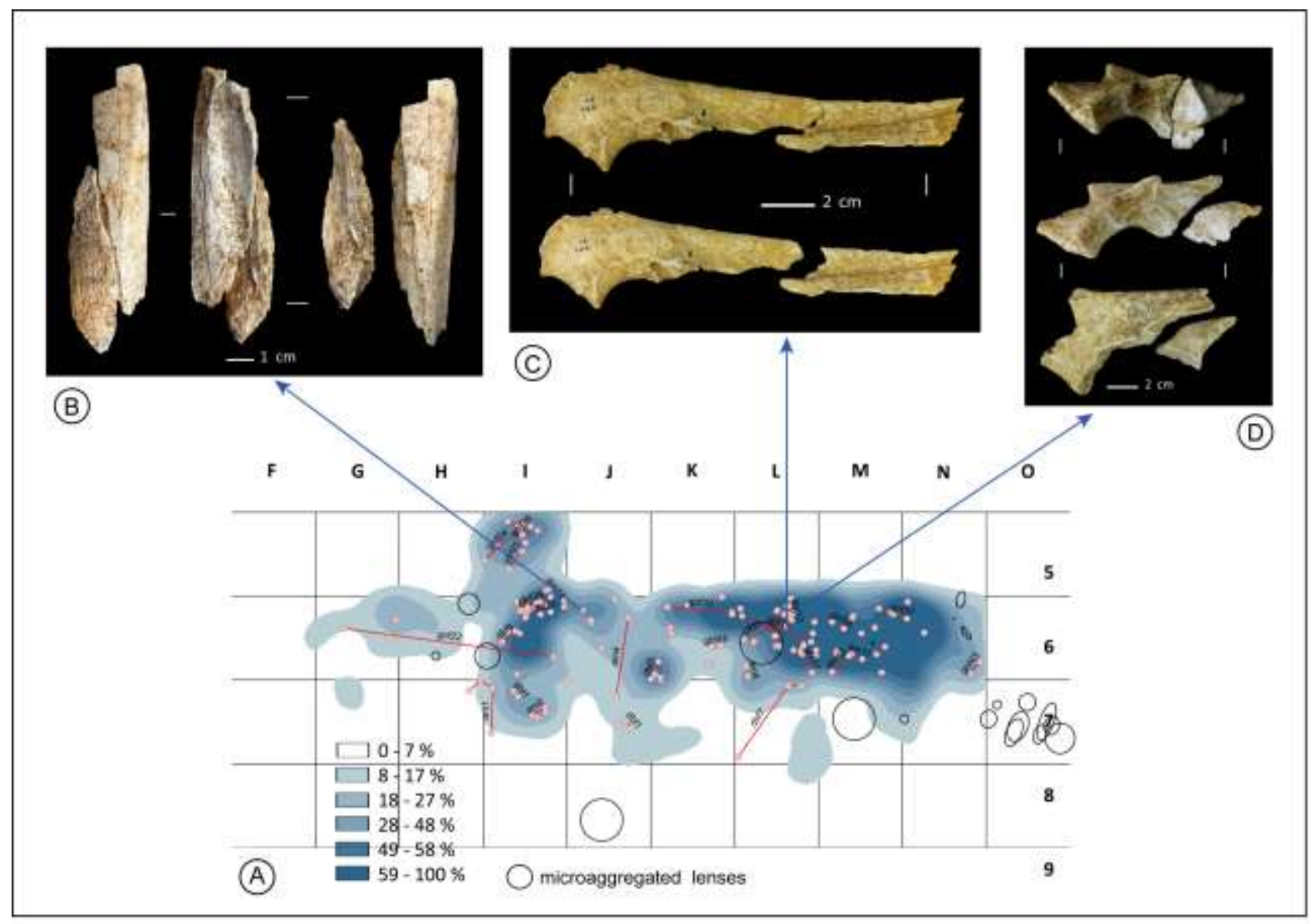

Fig. 9 A Density maps and visual the faunal assemblage, the faunal refits and their connection lines maps 1474 from Maras level 4.1, (Kernel density analysis); (B) Example of anatomical refit; C Example of green bone 1475 fracture refit and D Example of dry bone refit. (Photos D. Vettesse \& C. Daujeard) 


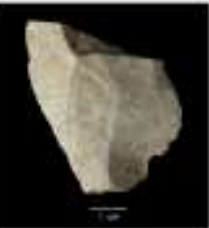

(D)
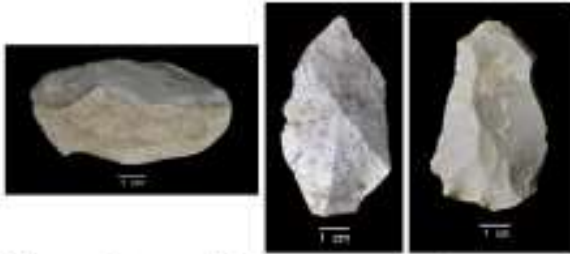

F G

H I

K L

M

N $\quad$ O

(A)
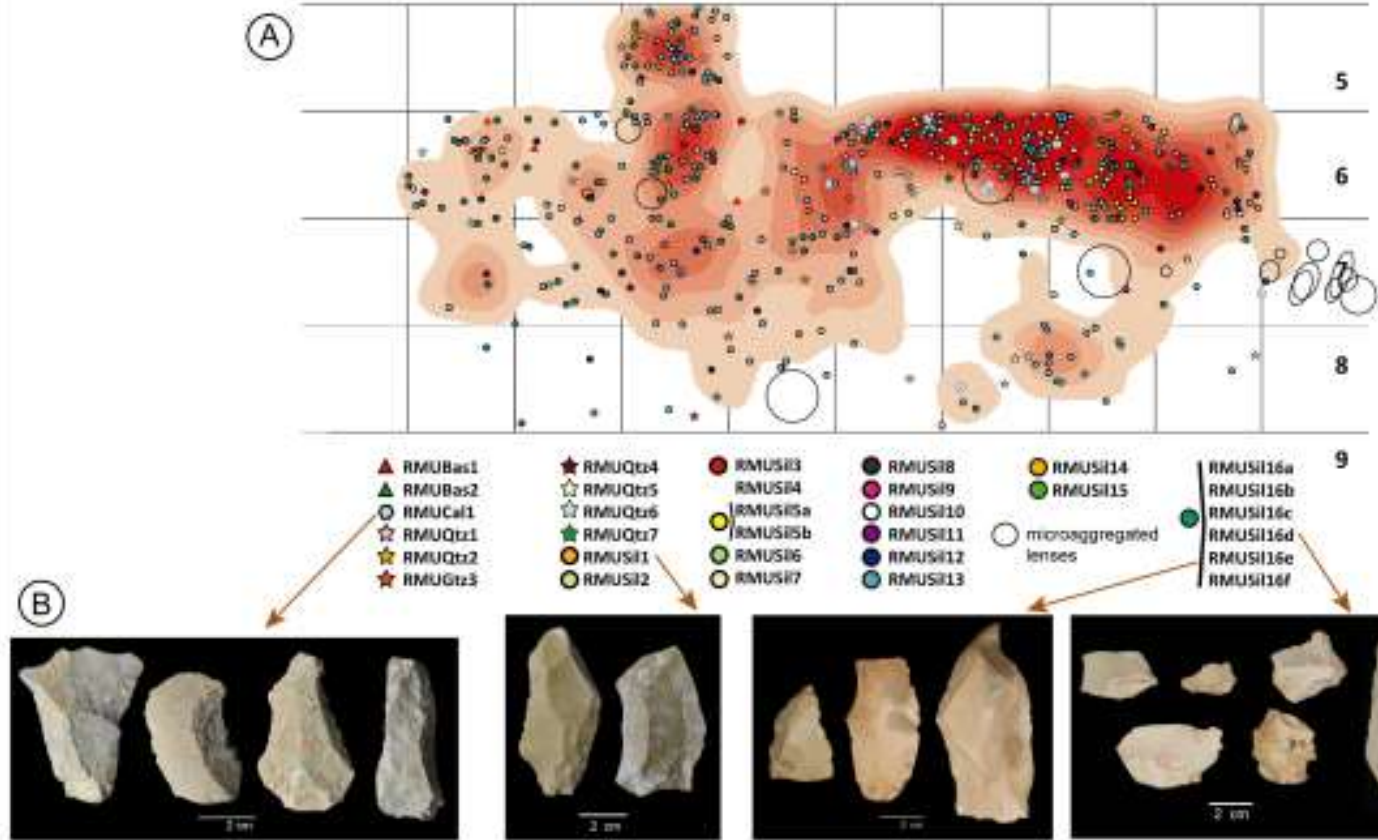

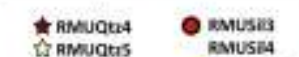

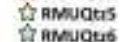

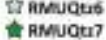

Onmusi1
Ormusi2

O)

O anusas

O Ravusas
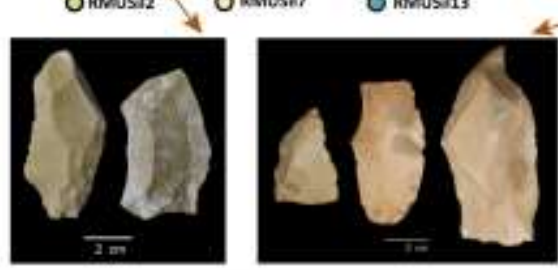

(E)

Fig. 10 A Spatial patterning of the lithic assemblage and RMU identified from Maras level 4.1 (Kernel density analysis); B Example of RMU in limestone; C Example of isolated pieces (tool kits) in quartzite; D Example of isolated pieces (tool kits) in flint; E Example of some of the identified RMUs in flint (Photos M.G. 


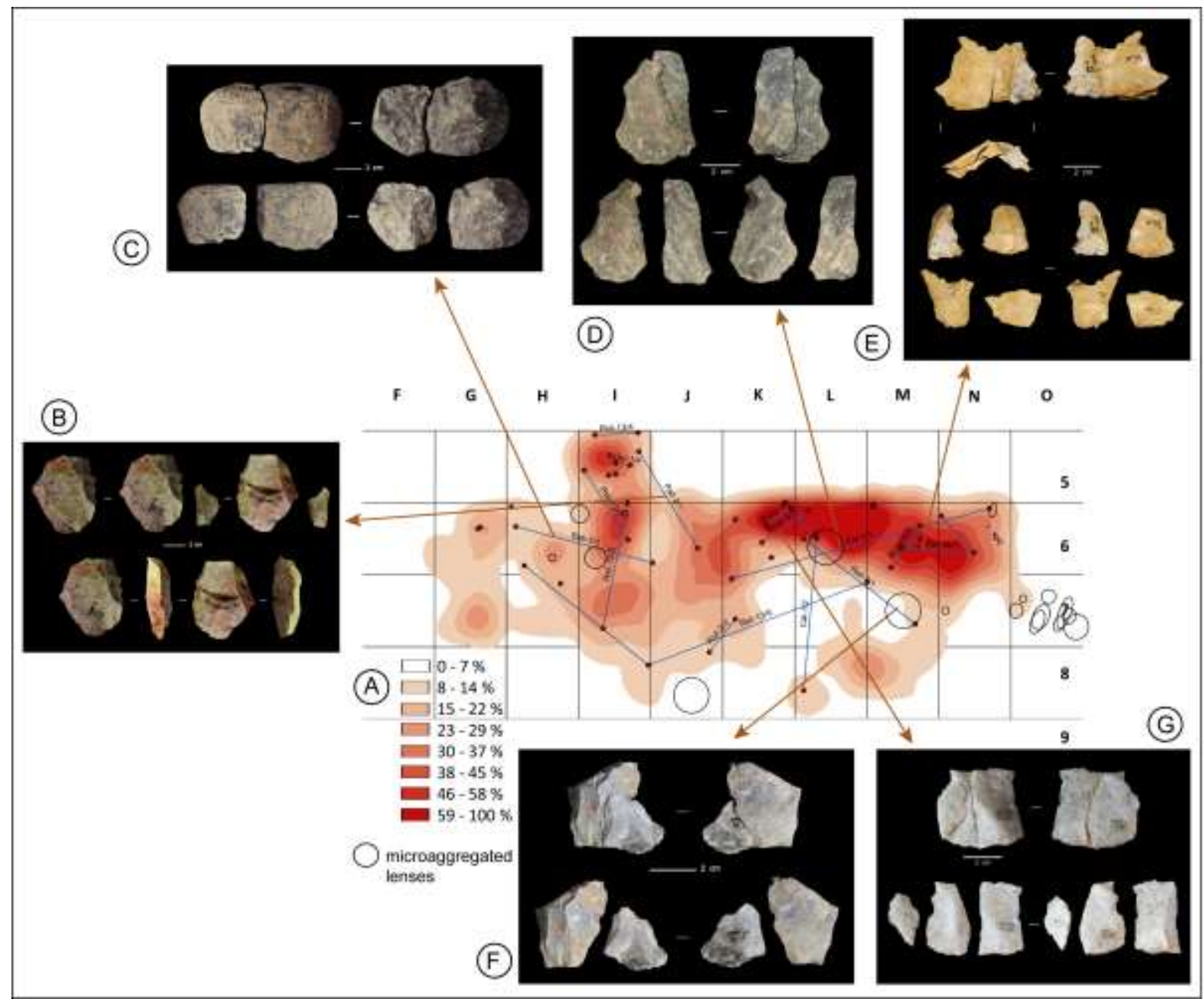

Fig. 11 A Density maps and visual maps of the lithic assemblage and refits identified with their connection lines from Maras level 4.1, (Kernel density analysis); B, E, F Example of refits in flint; C Example of refit in basalt; D Example of refit in limestone; G Example refit in quartz (Photos M.G. Chacón \& A. Eixea) 